Article

\title{
When the River Began-The Formation of River Motala Ström and Human Presence in the Early Holocene, Sweden
}

\author{
Jonas Bergman $\left.{ }^{1, *} \mathbb{(}\right)$, Anna Plikk ${ }^{1} \mathbb{D}$, Jens Heimdahl ${ }^{1}$, Linus Hagberg ${ }^{1}$, Fredrik Hallgren ${ }^{2}$, \\ Jan Risberg ${ }^{3}$ and Fredrik Molin ${ }^{1}$ \\ 1 The Archaeologists, National Historical Museums, 12653 Hägersten, Sweden; \\ anna.plikk@arkeologerna.com (A.P.); jens.heimdahl@arkeologerna.com (J.H.); \\ linus.hagberg@arkeologerna.com (L.H.); fredrik.molin@arkeologerna.com (F.M.) \\ 2 The Cultural Heritage Foundation, 72212 Västerås, Sweden; fredrik.hallgren@kmmd.se \\ 3 Department of Physical Geography, Stockholm University, 10691 Stockholm, Sweden; jan.risberg@geo.su.se \\ * Correspondence: jonas.bergman@arkeologerna.com
}

Received: 3 July 2020; Accepted: 21 August 2020; Published: 29 August 2020

\begin{abstract}
In conjunction with the extensive archaeological projects conducted at the current outlet of Sweden's second largest lake, Lake Vättern, macrofossil, pollen and diatom records have been studied from ${ }^{14} \mathrm{C}$-dated lake and river sediments from River Motala Ström in Motala and Lake Boren. These investigations have revealed sedimentary evidence of the Yoldia Sea regression, the Ancient Lake Vättern transgression, and the following stepwise river formation process. Around $9000 \mathrm{cal}$ BC, two small kettlehole basins at Strandvägen and Kanaljorden became isolated from the Baltic basin. As the ice sheet retreated further north, the isostatic uplift isolated the Vättern basin from the Baltic basin. Due to the uneven isostatic uplift, the basin tilted toward the south, and the Ancient Lake Vättern transgression started in Motala. The threshold in Motala at $92.5 \mathrm{~m}$ a.s.l. was reached around $7200 \mathrm{cal} \mathrm{BC}$, and River Motala Ström was formed. ${ }^{14} \mathrm{C}$-dated diatom records from Lake Boren, and shoreline deposits in Motala, confirm this event. The water level in Lake Vättern initially fell around $1.5 \mathrm{~m}$, and around $5800 \mathrm{cal} \mathrm{BC}$, a second erosional event cut down the threshold to modern day level. At this time, the Late Mesolithic settlements in Motala were established and expanded.
\end{abstract}

Keywords: River Motala Ström; Lake Vättern; river formation process; shoreline displacement; Mesolithic; Strandvägen; Kanaljorden

\section{Introduction}

River formation in formerly glaciated areas, where isostatic uplift and shore displacement is a dominating component of the postglacial landscape development, is a relatively poorly researched area cf [1,2]. This is not surprising, since most fluvial environments are erosional in character, continuously eroding, transporting, and redepositing its geological record, often making the stratigraphy very complex, and the absolute dating of events difficult $[3,4]$. The landscape below the highest coastline of southern Sweden is largely shaped by glaciations, subsequent isostatic uplift and eustatic changes. The river valleys in the province of Östergötland were roughly shaped during the last glacial, and early Holocene, by retreating ice sheets and covered by glaciolacustrine and marine clays during the Baltic Ice Lake and Yoldia Sea stages [5]. In the case of the Lake Vättern basin, which extends over $120 \mathrm{~km}$ from north to south (Figure 1), the differential isostatic uplift had a direct effect on the drainage, and a new river was formed during the early Holocene. Few river valleys in southern Scandinavia have been the stage for such intense Mesolithic activity as the river sites in Motala (Figure 1). To understand why this place has been such a focal point, the landscape and river development needs to be understood. In this 
multi-disciplinary paper, we report and discuss the relevant sediment stratigraphy, chronology and river formation processes that took place in Motala. The environmental data from the archaeological sites are discussed and corroborated by data from sediment cores retrieved from Lake Boren, downstream from Motala. We pay special attention to the chronology of the River Motala Ström formation process, and the local shoreline displacement in the Vättern basin.

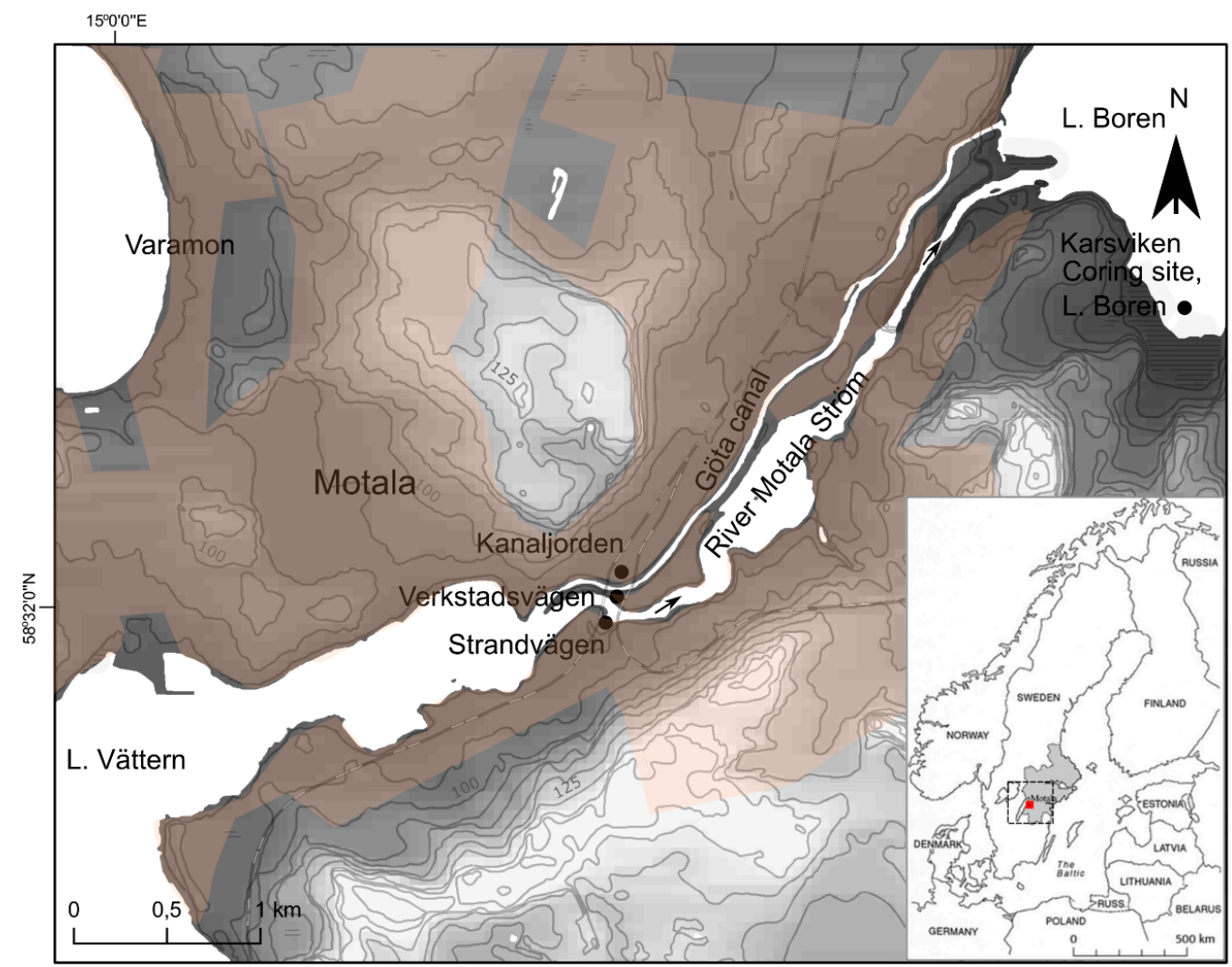

Figure 1. Elevation map with present-day River Motala Ström, the Strandvägen and Kanaljorden Mesolithic sites, and the coring site in Lake Boren. Lake Vättern had, during the early 20th century, a mean water level of $88.5 \mathrm{~m}$ a.s.l., and Lake Boren ca. $72 \mathrm{~m}$ a.s.l. Urban areas are marked in reddish color. Encapsulated: The town of Motala in east-central Sweden in red and the province of Östergötland highlighted in grey. The dashed box indicates Figure 2.

\section{Site Description}

The modern River Motala Ström in Motala is a form of entrenched meandering channel stream. It has during modern times been regulated, especially since the construction of a hydroelectric power plant in the 1920s, but earlier historical maps show that it has been relatively fixed, with limited stream bed erosion and very low sediment transport. The distance between Lake Vättern and Lake Boren is ca. $4 \mathrm{~km}$. Lake Vättern had, during the early half of 20th century, a mean water level of $88.5 \mathrm{~m}$ a.s.l. (between 87.97-89.08 m a.s.1.), a residence time of ca. 70 years and a mean run-off of $42 \mathrm{~m}^{3} / \mathrm{s}$ (data from Swedish Meteorological and Hydrological Institute).

Motala has been interpreted as a central place in the Mesolithic society of eastern central Sweden [6]. Three partly contemporary sites, dating between ca. $9000-4500$ cal BC have been excavated by River Motala Ström, the outflow of Lake Vättern (Figure 1).

The sites Kanaljorden and Verkstadsvägen are situated on the northern side of the river, whereas the site Strandvägen is located on the opposite southern side. Together, they comprise the largest and most complex Mesolithic settlement area known and excavated in this region. The areas at Verkstadsvägen and Strandvägen consist of central parts of the settlement, with several documented post-built 
dwellings, and the first excavated Mesolithic cemetery in central Sweden [7-10]. The Verkstadsvägen site contains no fluvial or aquatic sediment deposits.

Strandvägen is centered around $89 \mathrm{~m}$ a.s.l. on a low sandy hill, comprised of wave-washed till, forming a promontory out in the river, adjacent to both the inner bay of Lake Vättern and a shallow backwater downstream of the first rapids of the river (Figure 1). The backwater is well protected from waves by the hill directly to the west, and contains significant gyttja deposits. The site has been the subject of large-scale excavations, and contains, beside dwellings and funeral remains, thick occupation layers along the shore, and refuse layers in the gyttja of the riverbed. The earliest remains date to ca. $7000 \mathrm{cal} \mathrm{BC}[9,11]$.

Kanaljorden contains Early Mesolithic remains, as well as a Late Mesolithic ceremonial context, with human remains placed onto a stone-packing on the bottom of a shallow wetland. The site is situated about $100 \mathrm{~m}$ north of the current course of the river, and ca. $250 \mathrm{~m}$ east of Lake Vättern [12,13]. The local topography is dominated by a low ridge with postglacial sand in the east, and a wetland in the west. The wetland has two shallow basins, one to the north and one in the south. The wetland is today a bog, but had open water during the early Holocene. The wetland, and to some extent the western slope of the ridge, displays a chrono-stratigraphical sequence of layers from the Mesolithic, i.e., the period ca. $9500-4000 \mathrm{cal} \mathrm{BC}$. The situation is different on the top of the ridge, where finds from different periods of the Holocene occur in the same strata.

\section{Shoreline History of the Vättern Area}

When southern Lake Vättern was deglaciated ca. 11,000 cal BC, the Baltic basin was occupied by the Baltic Ice Lake, which was dammed by the retreating ice sheet to at least $25 \mathrm{~m}$ above the global sea level [14]. About $9800 \mathrm{cal} \mathrm{BC}$, the lowlands east and west of central Lake Vättern were deglaciated $[5,15]$ and as the ice sheet retreated north of Mt Billingen (Figure 2) at ca. $9600 \mathrm{cal} \mathrm{BC}$ the Baltic Ice Lake was drained down to sea level, marking the onset of the Yoldia Sea (9600-8750 cal BC). During that time, the Baltic basin was in contact with the sea through open straits across southern central Sweden [16-18]. Shore lines at $120 \mathrm{~m}$ a.s.l. mark the maximum level of the Yoldia Sea near Motala [5]. The shore displacement was rapid, and by $9150 \mathrm{cal} \mathrm{BC}$, sites down to $105 \mathrm{~m}$ a.s.l. south of Motala had been lifted above sea level $[19,20]$. At that time, the Vättern basin formed a bay with a northern connection to the Yoldia Sea (Figure 2).

As the Göta River and Otteid/Steinselva straits that connected the Yoldia sea with the North Sea were lifted above sea level, the next freshwater stage of the Baltic basin, the Ancylus Lake (8750-7750 cal BC), was initiated [16,18]. The differential isostatic uplift led to the northern part of the basin rising faster, and this N-S tilting of the Ancylus Lake initiated a transgression of the southern

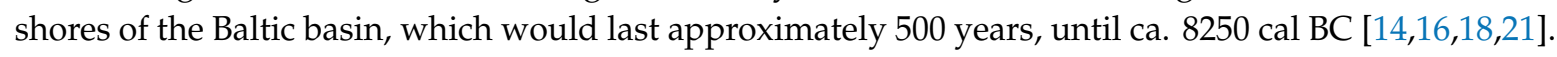
The transgression was most marked in the southern Baltic region, but can also be traced in southern central Sweden, e.g., east of Motala near Lake Boren and Linköping, where it is registered at $82 \mathrm{~m}$ and $76 \mathrm{~m}$ a.s.l. respectively $[22,23]$. The transgression was followed by a regressive phase as the new southern outlet across the Danish straits opened [14,16]. During this regression, the Närke strait at $105 \mathrm{~m}$ a.s.l. north of Lake Vättern (Figure 2) was exposed, and a land-bridge connected to northern Sweden was formed $[24,25]$. The Ancylus Lake stage was followed by the transitional Initial Littorina Sea (ca. 7750-6250 cal BC) and the brackish Littorina Sea as the sea level rose above the southern threshold, around 6450-5950 cal BC [14,26]. 


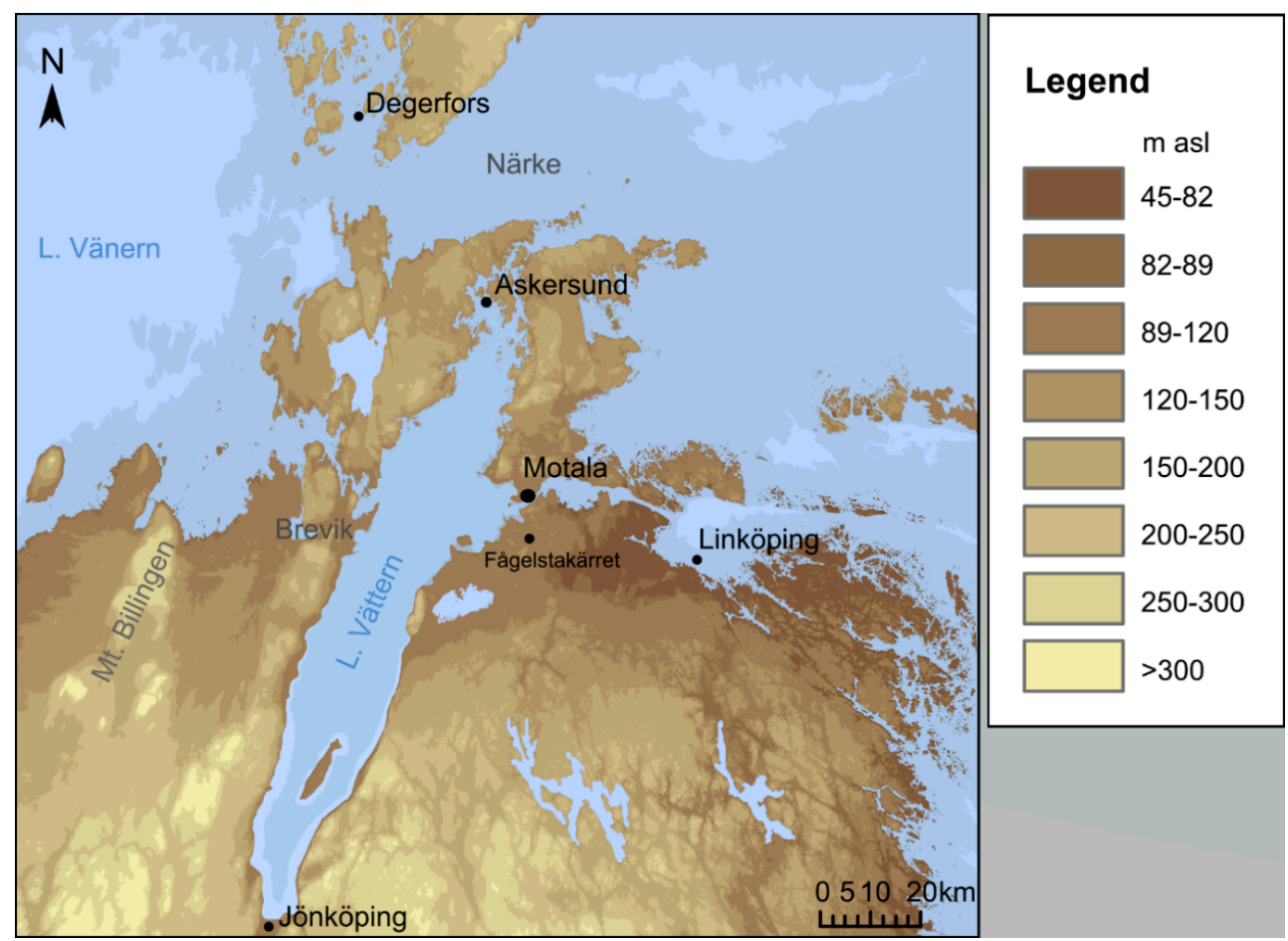

Figure 2. Map of central middle Sweden with the approximate extent of the Yoldia Sea at ca. $9000 \mathrm{cal}$ BC (following online maps at www.sgu.se). The investigated area is located at the eastern shore of Lake Vättern in Motala. Notably: $150 \mathrm{~m}$ a.s.l. = the highest shoreline of the Baltic Ice Lake near Motala [5], $120 \mathrm{~m}$ a.s.l. = the highest shoreline of the Yoldia Sea near Motala [5]. The elevation of the northern threshold of the Lake Vättern basin, close to Askersund, is $105 \mathrm{~m}$ a.s.l., and the elevation of the Kanaljorden and Strandvägen sites at Motala is around $89 \mathrm{~m}$ a.s.l. The highest shorelines of the Ancylus Lake east of Motala (Lake Boren), is $82 \mathrm{~m}$ a.s.1. [22].

The shoreline development of Lake Vättern is complex and was subject to intensive geological studies in the first half of the 20th century [22,27-30]. The more pronounced uplift towards the north, in combination with the elongated N-S extent of the lake, has led to a tilting of the lake surface towards the south. The southern shore of Lake Vättern is presently being submerged, and records from the formerly exposed ground show that it was $11 \mathrm{~m}$ below the present lake surface in the vicinity of Jönköping (Figure 2) [31], but the former shoreline can be traced down to at least $31 \mathrm{~m}$ below the present lake surface, near the southern end [32]. Near Motala, the water level is estimated to have been as low as about $80 \mathrm{~m}$ a.s.l., i.e., $8 \mathrm{~m}$ below the present-day shoreline, before the transgression started [27]. The tilting supposedly led to a shift in outlets, from a northern outlet located near Askersund at $105 \mathrm{~m}$ a.s.l. (Figure 2), to the present-day outlet at Motala, at $88.5 \mathrm{~m}$ a.s.l. [22]. It is likely that an initial drainage in the north existed [22], but eventually, the tilting made it impossible for any riverine outlets to be sustained northwards. The tilting also caused the lake level to rise in the whole basin, until the new outlet formed. The erosion of the glaciofluvial material at the Motala threshold led to a sudden lowering of the lake level and the preservation of marked shorelines-the Ancient Lake Vättern (ALV) limit, that can be followed around the northern shores of the lake. In Motala, the ALV shoreline is measured to be approximately $92.5 \mathrm{~m}$ a.s.1. [27].

Shoreline and lake isolation studies indicating that the Ancylus Lake did not reach above $85 \mathrm{~m}$ a.s.1. in the Motala-Linköping area $[23,27]$ suggested that Lake Vättern could not have been in contact with the Ancylus Lake at the Motala threshold. It was long assumed that Lake Vättern was isolated from the Yoldia Sea as the northern threshold was uplifted above the sea surface e.g., [22,27,30]. Recently, however, the isolation of Lake Vättern was dated to $7580 \mathrm{cal}$ BC [33], which would indicate that the 
northern connection remained open throughout the Ancylus Lake phase and into the Initial Litorina Sea. At that time, the Ancylus Lake east of Motala was below $76 \mathrm{~m}$ a.s.l. [23].

Regardless of varying geological estimates and interpretations, two basic facts can be considered as established, and form the basis of our discussion:

(1) The River Motala Ström did not form immediately after deglaciation.

(2) There was a transgression in the Vättern basin during the early Holocene, resulting in the formation of River Motala Ström.

\section{Methods}

Sediment samples were collected from several sections with fluvial sand, peat and gyttja layers. The sampling was performed on 12 sections at Strandvägen [34] and 8 sections at Kanaljorden [35], using monolith boxes. The 1-m segments of the sediment profiles were carefully wrapped in plastic and transported to the laboratory at Stockholm University, for cold storage and subsequent sub-sampling. Sediment units/layers were correlated based on sediment properties and pollen/macrofossil assemblages.

\subsection{Macrofossil Analysis}

Samples for macrofossil analysis were taken in vertical sections; samples measuring ca. 0.5-1 L. Samples were prepared by wet-sieving (mesh size $0.25 \mathrm{~mm}$ ), and in some cases, when sand and gravel occurred, by flotation, according to [36]. The identifications of seeds were carried out by consulting reference collections and identification keys, especially [37-39] and [40]. Sand content was estimated by sieving $(80 \mu \mathrm{m})$, and the silt/clay fractions were estimated macroscopically.

\subsection{Pollen Analysis}

Pollen samples $\left(2 \mathrm{~cm}^{3}\right)$ were prepared according to method A, as described by [41]. The taxonomy and identification of pollen and spore taxa follow [42], and identifications were confirmed by comparison with pollen reference collections. A Nikon microscope was used at $\times 400$ and $\times 1000$ magnification. At least 400 tree pollen grains were counted in each sample.

\subsection{Lake Boren Sediment Coring}

In order to date the breakthrough of River Motala Ström into Lake Boren, a sediment coring was performed at the centre of Karsviken, close to the river outlet (Figure 1). A Russian corer was used to retrieve core sections $100 \mathrm{~cm}$ long and $5 \mathrm{~cm}$ ø. In total, $3.5 \mathrm{~m}$ of sediment was retrieved from five parallel cores. Then, $1-\mathrm{cm}$ slices of sediment were sampled every $5 \mathrm{~cm}$ for diatom analysis. Where necessary, parallel cores were correlated, and several 2-cm slices from the same level were combined to find enough terrestrial macrofossil material. The sediment was deflocculated, wet sieved at $500 \mu \mathrm{m}$, and the macrofossils were dried overnight at $50^{\circ} \mathrm{C}$. Samples were sent to the Ångström Laboratory in Uppsala for ${ }^{14} \mathrm{C}$-dating and calibrated using Oxcal v. 4.2.4. [43], and the INTCAL13 calibration data set [44]. The calibrated dates were combined into an age-depth plot.

\subsection{Diatom Analysis}

Permanent slides for diatom analysis were prepared according to [45]. The residue was mounted in Naphrax high resolution mountant (Brunel Microscopes Ltd., Wiltshire, UK).Counting was performed under $\times 1000$ magnification using immersion oil. Count sums ranged between 100-190 diatoms/sample. Species identification was carried out mainly with the aid from [46-49]. The species were classified after salinity preferences. Taxa typical for the Ancylus Lake were distinguished from other freshwater taxa, following e.g., [50,51]. 


\section{Results and Interpretation}

Of all studied sections at Kanaljorden and Strandvägen, the most complete sediment stratigraphy was found in section C 13059 from Strandvägen, and $\log 3$ from Kanaljorden [35]. Here we focus on data from the Lake Boren sediment core, and section C 13059, where sediments from all interpreted geological events are preserved (i.e., with least erosion and most deposition), but make correlations and comparisons with other sections from the sites. From the Kanaljorden site, we focus on dated stratigraphical units.

\subsection{Lake Boren Sediment Records}

The diatom stratigraphy has been divided into four zones, which are presented in Figure 3. Zone 1 is dominated by taxa typical for the late Ancylus Lake [50-52]; Aulacoseira islandica, Ellerbeckia arenaria, Amphora pediculus and Epithemia turgida. In zone 2, indifferent and freshwater taxa increase, tentatively interpreted as a result of the isolation of Lake Boren. According to the age-depth plot (Figure 4, Table 1), the isolation is dated to $8250 \mathrm{cal} \mathrm{BC.} \mathrm{During} \mathrm{this} \mathrm{initial} \mathrm{phase} \mathrm{of} \mathrm{Lake} \mathrm{Boren,} \mathrm{it} \mathrm{is} \mathrm{likely}$ that $\mathrm{pH}$ was enhanced by surrounding limestone bedrock $[5,53]$. This is also reflected in the diatom flora, since Rhoicosphaenia abbreviata is common [54]. Beside this taxon, the indifferent Cocconeis placentula, Pseudostaurosira brevistriata and freshwater living Aulacoseira ambigua, Cyclotella radiosa and Gomphonema spp. appear in zone 2. The relatively high abundance of planktonic diatoms and the deposition of laminated silty gyttja clay in this zone indicate relatively deep and well-stratified waters. In zone 3 , freshwater taxa decrease, and indifferent taxa increase, especially Staurosira construens, Staurosirella lapponica and Pseudostaurosira brevistriata. These taxa are known as opportunists, i.e., they flourish during periods of pronounced changes in the environment, e.g., in water chemistry cf $[55,56]$ This situation is likely to have occurred when water from Lake Vättern started to flow into the Lake Boren basin from the west, lowering the $\mathrm{pH}$ values in Lake Boren. Oxygenation of the bottom waters during this phase leads to increased bioturbation and a shift to non-laminated sediments. According to the age-depth plot this phase, representing the opening of the spillway over the Motala threshold and establishment of River Motala Ström, started around 7200-6900 cal BC (age from linear interpolation in Figure 4), and lasted ca. 1000 years (Figures 3 and 4). In zone 4 (beginning around 6200-5900 cal BC), the situation stabilized, causing a distinct decrease in Staurosirella lapponica, and common freshwater taxa were established. Several new taxa are introduced, e.g., Cymbellafalsa diluviana, Neidium iridis and Pinnularia spp.

Table 1. ${ }^{14} \mathrm{C}$-dates dates from the Lake Boren sediment core.

\begin{tabular}{|c|c|c|c|c|}
\hline Depth (cm) & Lab. $\mathrm{Nr}$ & $\delta^{13} C$ VPDB & ${ }^{14} \mathrm{C}$ age $\mathrm{BP}$ & Age cal BC $(2 \sigma)$ \\
\hline 447.5 & Ua-51176 & -29.3 & $6156 \pm 38$ & 5215-5002 \\
\hline 542.5 & Ua-51177 & -26.5 & $8708 \pm 43$ & $7936-7597$ \\
\hline 557.5 & Ua-51178 & -25.5 & $8847 \pm 46$ & $8213-7787$ \\
\hline 566.5 & Ua-51179 & -27.0 & $9137 \pm 33$ & $8451-8279$ \\
\hline
\end{tabular}

The dating of the isolation of Lake Boren, with a threshold at approximately $76 \mathrm{~m}$ a.s.l., at $8250 \mathrm{cal}$ BC, agrees with earlier studies of isolation basins from the area around Linköping, suggesting that lakes with threshold elevations in the interval 72 to $77.6 \mathrm{~m}$ a.s.l. [23] were isolated from the Ancylus Lake. The isolation is likely to have taken place following the Ancylus transgression, which ended in approximately $8250 \mathrm{cal} \mathrm{BC} \mathrm{[18].}$ 


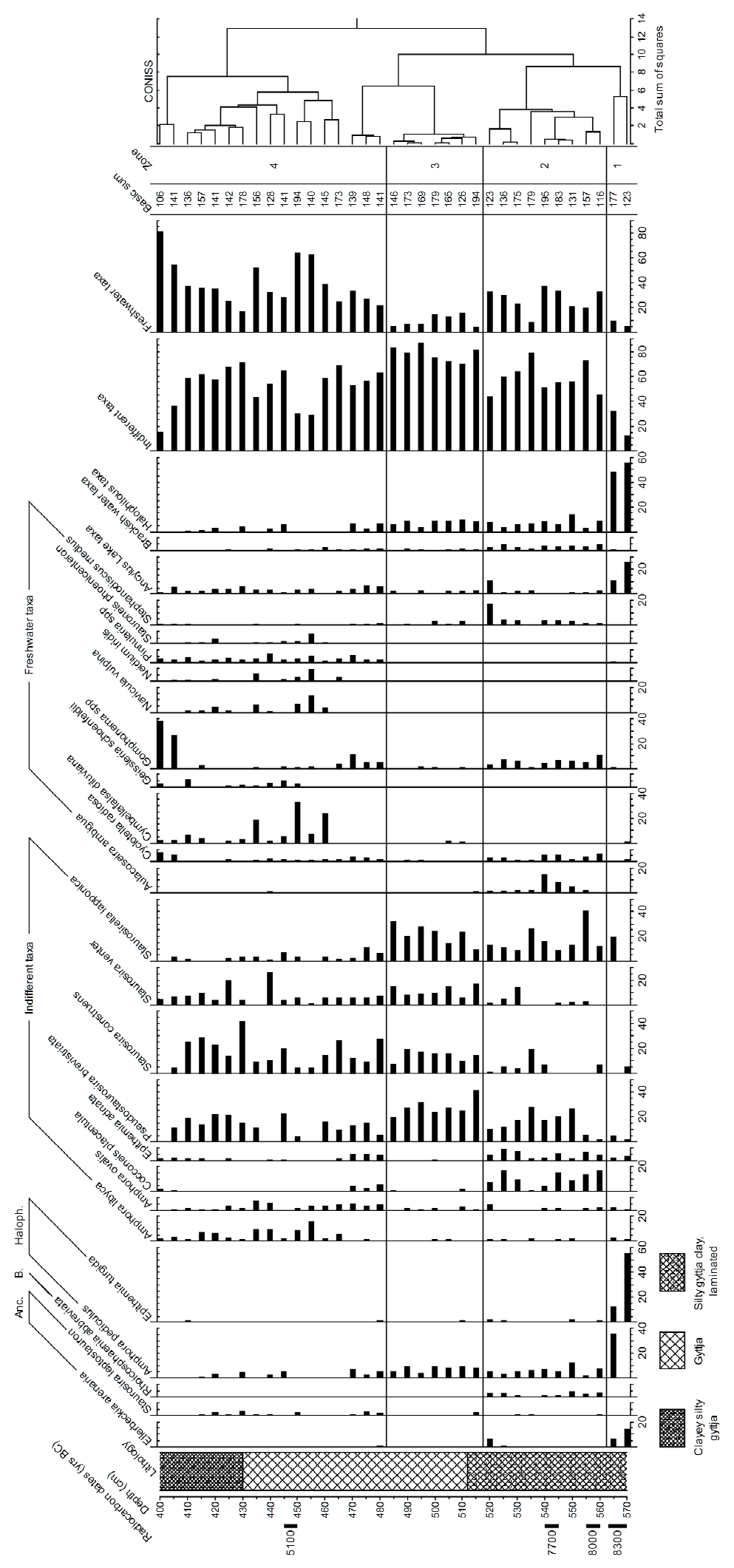

Figure 3. Diatom data from Lake Boren. 


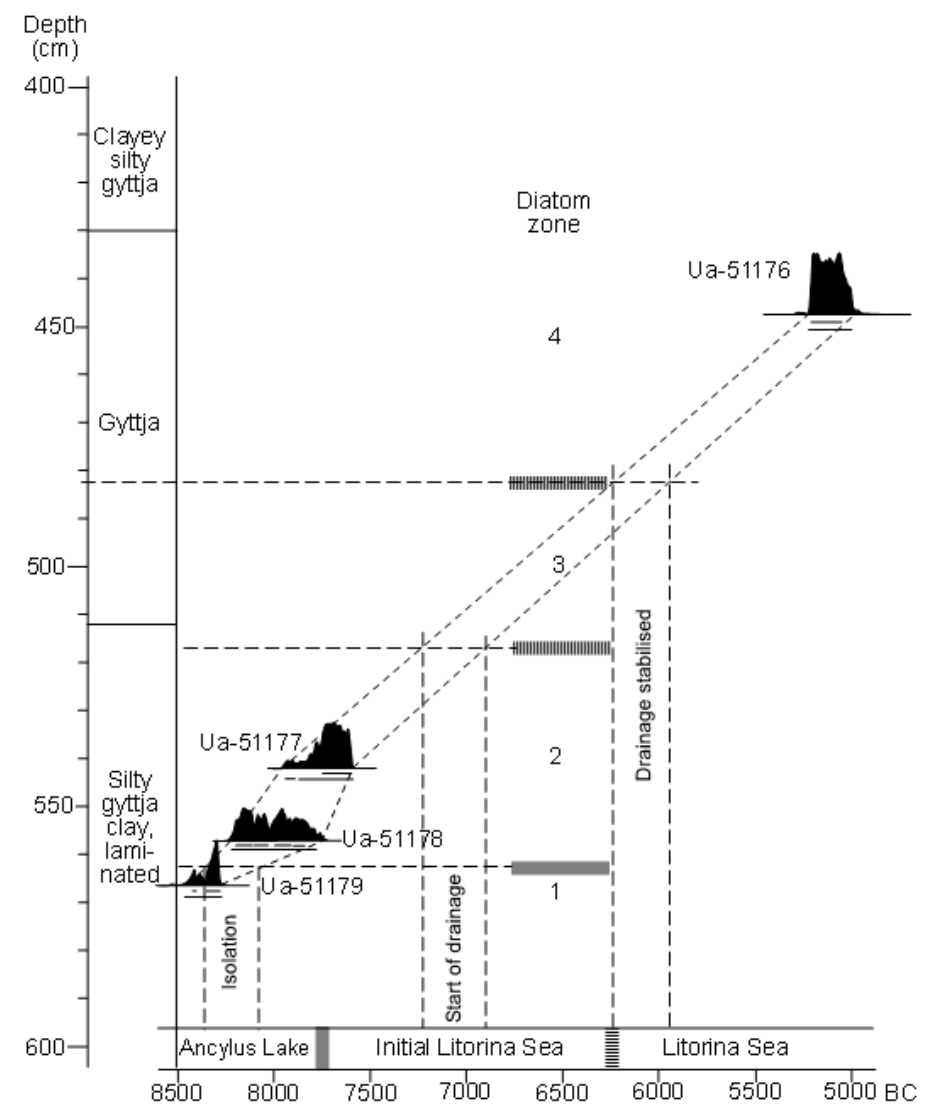

Figure 4. Chronology and sediment stratigraphy of sediment core from Karsviken in Lake Boren. Age-depth interval is based on linear interpolation of ${ }^{14} \mathrm{C}$-dates ( $2 \sigma$ error).

\subsection{Strandvägen Sediment Records}

Eleven macrofossil samples were analyzed directly from section C 13,059, but many more from adjacent sections. The text below describes results from mainly section $C 13,059$, but also from easily correlated sections. All terrestrial, telematic and aquatic plants were identified, as well as lithic, faunal, and archaeological macroscopic remains (Figure 5).

A total number of 29 pollen samples were analyzed from fluvial and aquatic sediments, and at least 400 tree pollen grains were counted in each sample. From section C 13,059, a total of 20 pollen samples were analyzed, and these are presented in Figure 6. To enhance the chronostratigraphical power of the pollen analysis, samples were screened at a lower magnification for pollen grains like Alnus, Tilia, Picea and Cerealia. The screening was done using 3-4 glass slides and a screening sum equivalent of ca. 2000 pollen. Pollen detected during screening is presented as $0.5 \%$ in Figure 6.

The lowermost aquatic sediment in the stratigraphy (in several sections, from both Kanaljorden and Strandvägen) is a light brown-grey clay, identified as postglacial clay $[34,35]$. The uppermost part of the clay sediment contains a few macrofossils of Empetrum nigrum and Potamogeton sp. [34] These were probably deposited in a shallow near-shore environment during the last phase of the Yoldia Sea. There is little evidence of any erosion at the contact to the overlaying calcareous gyttja in section C 13,059. 


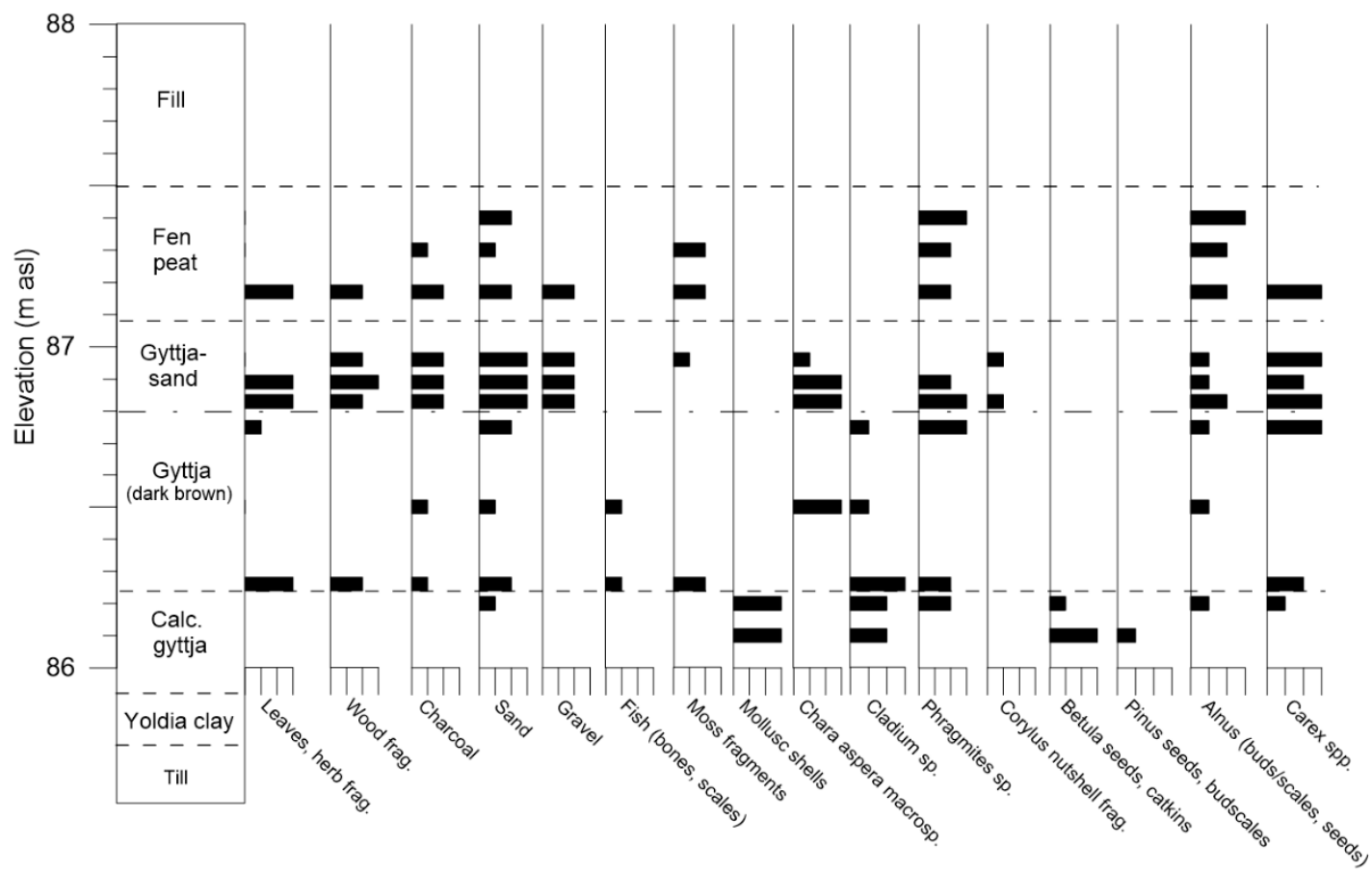

Figure 5. Macrofossil remains from section C 13,059 at Strandvägen. Mainly terrestrial and telematic/submerged organic plant material is presented, but lithic, faunal and archaeological macroscopic remains, relevant for water depth reconstruction and changes in the sedimentary environment, are also included. The material is quantified according to a three graded scale (1-3). For fragmented material, 1 represents single occurrences in the whole sample, 3 represents material dominating the sample, and 2 is the intermediate grade used when a type of macrofossil could be described as "common" within the sample. Seeds/fruits of Cladium, Carex, and all tree taxa are presented as amalgamated with tissue fragments, catkin scales, budscales and macrospores. The scale is relative to the taxa in all samples; generally, 1 represents $1-9$ diaspores, and 3 represents $>50$ diaspores.

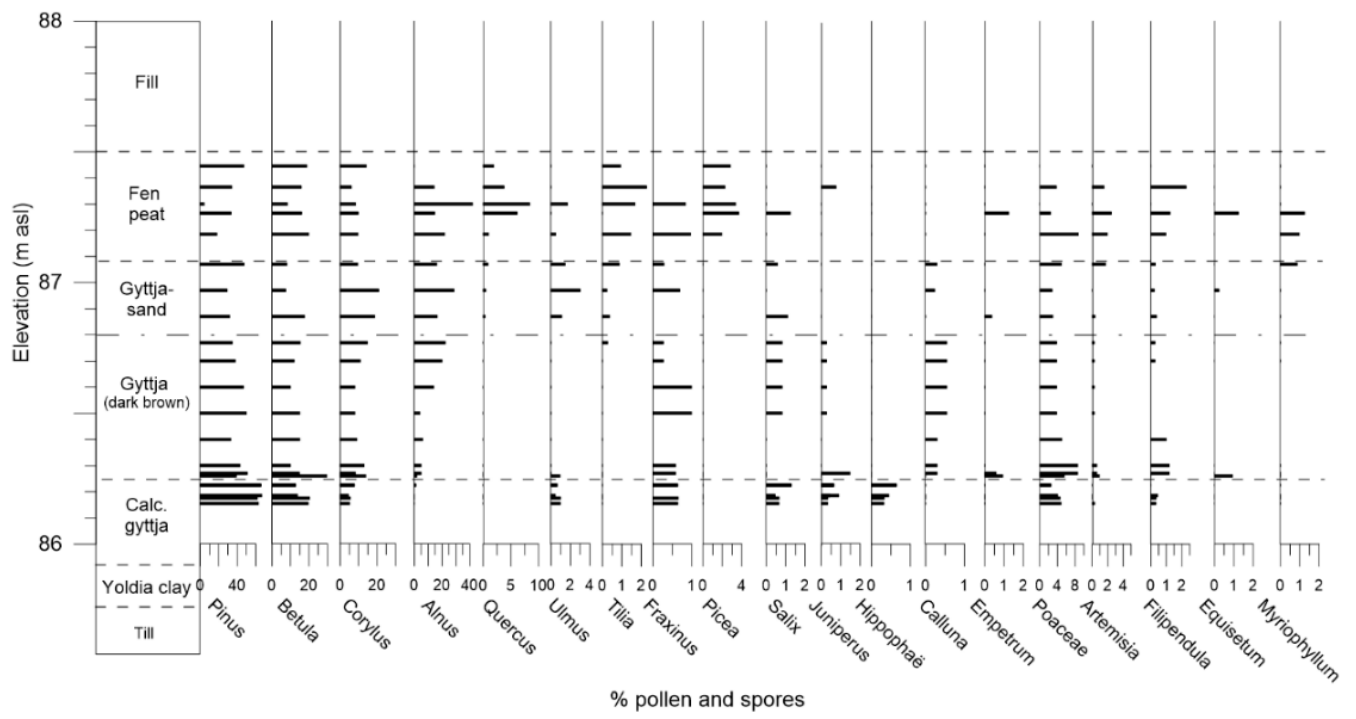

Figure 6. Pollen percentage data from section C 13,059.

From the sandy calcareous gyttja, a total of nine macrofossil samples were analyzed, and two from section C 13,059 (Figure 5). The calcareous gyttja is characterized by shell fragment of mollusks 
and some precipitated carbonates (calcareous sand), and the clay/silt content increase slightly upwards from ca. $86.20 \mathrm{~m}$ a.s.l. The layer represents the shallow (but with low wave-energy) freshwater environment, in the small isolated basin called Lake Strandvägen (isolated after ca. $8800 \mathrm{cal} \mathrm{BC}$ ). Remains of subaquatic mosses (Figure 5), and charales, e.g., Drepanocladus spp., Chara cf aspera and Nitella cf opaca, reflect the bottom flora in the shallower parts of Lake Strandvägen and Kanaljorden, but are absent in section C 13,059; probably because the section is from a deeper part of the basin, i.e., $>2 \mathrm{~m}$ water depth [57]. Regular occurrence of terrestrial plant macrofossils, such as birch (Betula spp.), pine (Pinus sylvestris L.), lesser spearwort (Ranunculus flamula L.) and sedge (Carex spp.) indicate relative closeness to the shore, and possibly a rising water table leading to a successive inundation of the shore flora. The pollen data from the lower parts of the calcareous gyttja (Figure 6) show that alder (Alnus glutinosa L.) has not yet spread on the local shores, until the uppermost part of the calcareous gyttja, where alder pollen occur. This implies that the lower part of the calcareous gyttja is older than at least $7500 \mathrm{cal} \mathrm{BC}$, when alder pollen increases in the Motala area [19]. However, in the uppermost part of the calcareous gyttja, alder pollen appears (Figure 6), and fruits of alder occur. On the dry land, around the small kettlehole lakes in Motala, pine, birch, hazel and grasses dominated the vegetation, with some elm (Ulmus) and ash (Fraxinus). There is no charcoal indicating human occupation in the calcareous gyttja, but a couple of edible weeds occur, such as shepherds-purse (Capsella bursa-pastoris L.), fat hen (Chenopodium album L.), and a seed of rowan berry (Sorbus aucuparia L.) The presence of those plants is notable, and possibly an indication of human presence, as implied by finds from Kanaljorden [13,35]. The uppermost part of the calcareous gyttja is dated to 8200-7600 cal BC (Figure 7, Table 2).

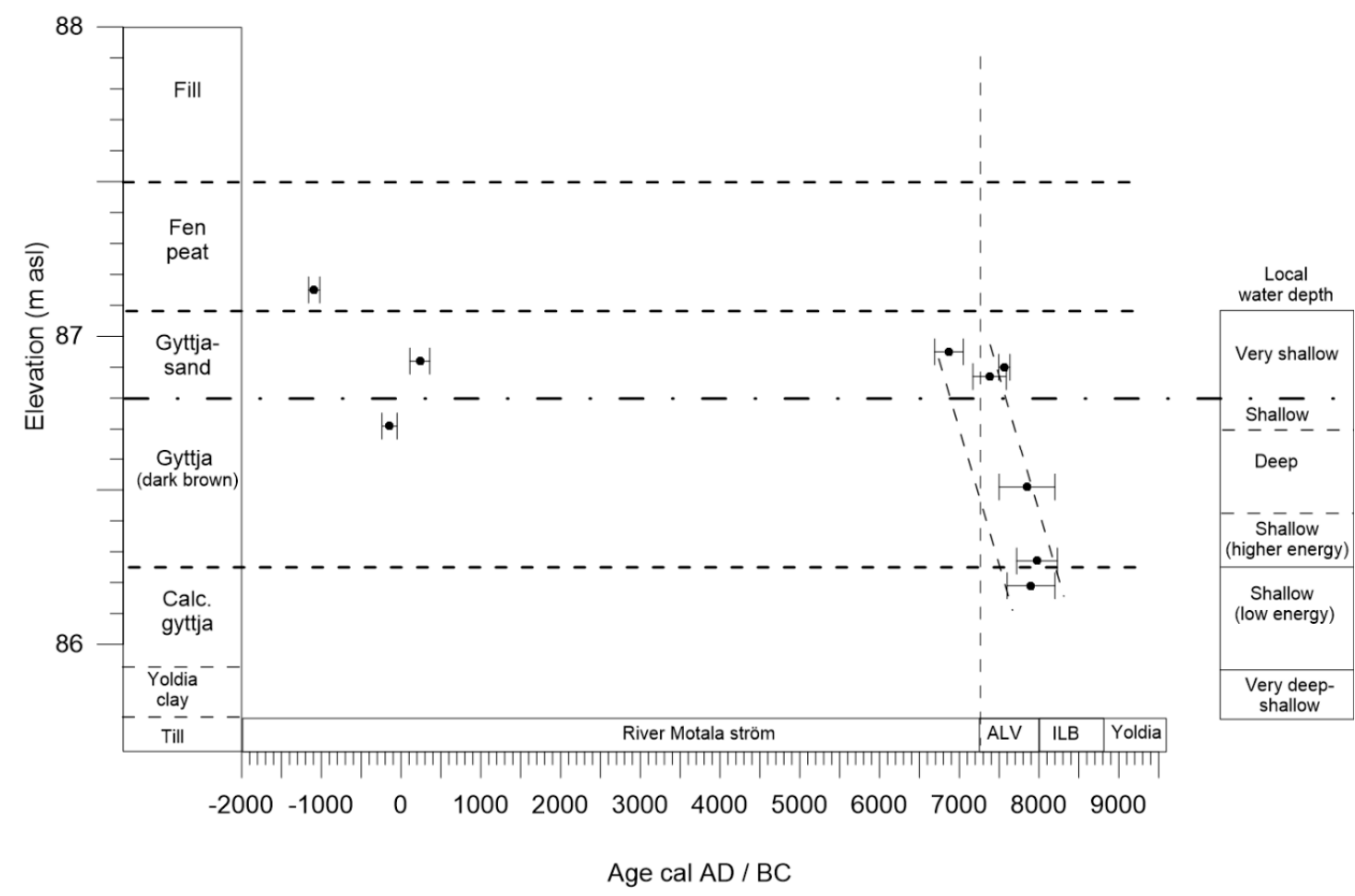

Figure 7. Stratigraphy and ${ }^{14} \mathrm{C}$-dates ( $2 \sigma$ error) of section $C 13,059$. The section contains sediment from the deepest part of the investigated basins in Motala. ALV = Ancient Lake Vättern transgression. ILB = Isolated Lake Basin (Lake Strandvägen). Diagonal dashed lines are suggested age-depth interval for the uppermost calcareous gyttja (ILB gyttja), dark brown gyttja (ALV gyttja) and lowermost gyttja-sand (River sediment). The boundary between the dark brown gyttja and the gyttja-sand is gradual and mainly based on sampling levels of macrofossils. The local water depth reconstruction is based on macrofossils and sediment properties, such as sand and silt/clay content. 
Table 2. ${ }^{14} \mathrm{C}$ dates from Holocene stratigraphical sequences in Motala (Strandvägen and Kanaljorden). The ${ }^{14} \mathrm{C}$ ages were calibrated using the OxCal 4.2.4 software [43], and the INTCAL 13 calibration data set [44]. All dates relevant for stratigraphical interpretation are included. Several archaeological radiocarbon dates (over 200) are not included [58,59], and younger dates (Corylus) from section C 13059 are omitted but shown in plots.

\begin{tabular}{|c|c|c|c|c|c|c|c|c|}
\hline Site & Locality & $\begin{array}{l}\text { Section, Archaeological } \\
\text { Context }\end{array}$ & Sediment Layer & m a.s.l. & Sample No & Dated Material & $C^{14}$-Age BP & $\begin{array}{l}\text { Age cal a BC } \\
(2 \sigma)\end{array}$ \\
\hline \multirow[t]{18}{*}{ Strandvägen } & Cemetery & Mesolithic burial 02 & Sandy filling & 91.1 & Ua-30873 & Charred Corylus & $7963 \pm 45$ & $7050-6690$ \\
\hline & & Mesolithic burial 10 & Sandy filling & 90.85 & Ua-31398 & Querqus charcoal & $8099 \pm 53$ & $7310-6820$ \\
\hline & & Mesolithic burial 09 & Sandy filling & 90.32 & Ua-31397 & Pinus charcoal & $8035 \pm 52$ & $7140-6750$ \\
\hline & Backwater & C 5257 & $\begin{array}{l}\text { River sediment } \\
\text { (gyttja/sand) }\end{array}$ & 87.78 & Ua-31810 & Nutshell Corylus & $7187 \pm 122$ & $6400-5800$ \\
\hline & $\begin{array}{l}\text { Western part of } \\
\text { backwater }\end{array}$ & C 4248 & $\begin{array}{l}\text { River sediment } \\
\text { (gyttja/sand) }\end{array}$ & 87.76 & Ua-29700 & Seeds (Betula) & $1566 \pm 65$ & $-350--640$ \\
\hline & & C 4248 & $\begin{array}{l}\text { River sediment } \\
\text { (gyttja/sand) }\end{array}$ & 87.74 & Ua-31811 & Nutshell Corylus & $7301 \pm 217$ & $6600-5700$ \\
\hline & & C 4248 & $\begin{array}{l}\text { River sediment } \\
\text { (gyttja/sand) }\end{array}$ & 87.7 & Ua-31812 & Nutshell Corylus & $6522 \pm 51$ & $5610-5370$ \\
\hline & & C 4248 & $\begin{array}{l}\text { River sediment } \\
\text { (gyttja/sand) }\end{array}$ & 87.67 & Ua-29701 & Nutshell Corylus & $6749 \pm 38$ & $5730-5610$ \\
\hline & & C 4248 & $\begin{array}{l}\text { River sediment } \\
\text { (gyttja/sand) }\end{array}$ & 87.65 & Ua-29702 & $\begin{array}{l}\text { Seeds (Betula, Pinus, } \\
\text { Scirpus/Carex) }\end{array}$ & $9119 \pm 85$ & $8650-8200$ \\
\hline & & C 4248 & $\begin{array}{l}\text { River sediment } \\
\text { (gyttja/sand) }\end{array}$ & 87.58 & Ua-31813 & Nutshell Corylus & $6684 \pm 40$ & $5670-5520$ \\
\hline & & C 4248 & $\begin{array}{l}\text { River sediment } \\
\text { (gyttja/sand) }\end{array}$ & 87.52 & Ua-31622 & Seeds (fen plants) & $9038 \pm 75$ & $8450-7960$ \\
\hline & & C 4248 & $\begin{array}{l}\text { River sediment } \\
\text { (gyttja/sand) }\end{array}$ & 87.49 & Ua-31621 & Seeds (fen plants) & $9419 \pm 72$ & $9150-8450$ \\
\hline & & C 4248 & $\begin{array}{l}\text { River sediment } \\
\text { (sandy gyttja) }\end{array}$ & 87.48 & Ua-31249 & Wood (Pinus) & $9045 \pm 58$ & $8430-7980$ \\
\hline & & C 4248 & $\begin{array}{l}\text { River sediment } \\
\text { (sandy gyttja) }\end{array}$ & 87.41 & Ua-29984 & Seed (Menyant-hes) & $9356 \pm 78$ & $8820-8330$ \\
\hline & $\begin{array}{l}\text { Eastern part of } \\
\text { backwater }\end{array}$ & C 13059 & $\begin{array}{l}\text { River sediment } \\
\text { (gyttja/sand) }\end{array}$ & 86.9 & Ua-54534 & Wood (Pinus) & $8532 \pm 38$ & $7600-7530$ \\
\hline & & C 13059 & $\begin{array}{l}\text { River sediment } \\
\text { (gyttja/sand) }\end{array}$ & 86.9 & Ua-31815 & Wood (Pinus) & $7961 \pm 46$ & $7050-6690$ \\
\hline & & С 13059 & River sediment & 86.8 & Ua-31816 & Wood (Salix) & $8354 \pm 95$ & $7590-7170$ \\
\hline & & С 13059 & Dark brown gyttja & 86.5 & Ua-31818 & Wood (Salix) & $8673 \pm 100$ & $8200-7500$ \\
\hline
\end{tabular}


Table 2. Cont

\begin{tabular}{|c|c|c|c|c|c|c|c|c|}
\hline Site & Locality & $\begin{array}{c}\text { Section, Archaeological } \\
\text { Context }\end{array}$ & Sediment Layer & m a.s.l. & Sample No & Dated Material & $C^{14}$-Age BP & $\begin{array}{l}\text { Age cal a BC } \\
(2 \sigma)\end{array}$ \\
\hline \multirow{14}{*}{ Kanaljorden } & \multirow{13}{*}{ Southern basin } & C 13059 & Dark brown gyttja & 86.3 & Ua-31819 & $\begin{array}{c}\text { Seeds } \\
\text { (Scirpus/Carex) }\end{array}$ & $8834 \pm 66$ & $8230-7720$ \\
\hline & & C 243837 & Calcareous gyttja & 86.2 & Ua-31820 & $\begin{array}{c}\text { Seeds } \\
\text { (Scirpus/Carex) }\end{array}$ & $8783 \pm 48$ & $8200-7600$ \\
\hline & & $\log 3$ & Peaty gyttja & 89.59 & Ua-41617 & $\begin{array}{l}\text { Seeds (Betula) } \\
\text { charcoal }\end{array}$ & $6836 \pm 43$ & $5808-5638$ \\
\hline & & $\log 3$ & $\begin{array}{l}\text { Cobelly gravelly } \\
\text { sand }\end{array}$ & 89.46 & Ua-41616 & $\begin{array}{l}\text { Seeds, catkin-bracts } \\
\text { (Betula) }\end{array}$ & $9016 \pm 95$ & $8468-7835$ \\
\hline & & $\log 3$ & Calcareous gyttja & 89.36 & Ua-41615 & $\begin{array}{l}\text { Budscale, seed, bud } \\
\text { (Betula) }\end{array}$ & $9876 \pm 186$ & $10072-8806$ \\
\hline & & $\log 3$ & Calcareous gyttja & 89.23 & Ua-41614 & $\begin{array}{c}\text { Seeds } \\
\text { (Scirpus/Carex) }\end{array}$ & $9699 \pm 62$ & $9288-8840$ \\
\hline & & P2861 & Sandy gyttja & 89.56 & Ua-39277 & Charcoal & $8201 \pm 43$ & $7340-7070$ \\
\hline & & P2861 & Sandy gyttja & 89.46 & Ua-41616 & Seeds (Betula) & $9016 \pm 95$ & $8468-7935$ \\
\hline & & P2861 & $\begin{array}{l}\text { Cobelly gravelly } \\
\text { sand }\end{array}$ & 90.88 & Ua-51087 & $\begin{array}{l}\text { Charcoal, seeds } \\
\text { (Corylus) }\end{array}$ & $6903 \pm 51$ & $5899-5674$ \\
\hline & & P2861 & $\begin{array}{l}\text { Cobelly gravelly } \\
\text { sand }\end{array}$ & 90.47 & Ua-51085 & $\begin{array}{l}\text { Charcoal, seeds } \\
\text { (Alnus) }\end{array}$ & $7223 \pm 51$ & $6215-6011$ \\
\hline & & P2861 & $\begin{array}{l}\text { Cobelly gravelly } \\
\text { sand }\end{array}$ & 90.45 & Ua-51086 & $\begin{array}{l}\text { Charcoal, seeds } \\
\text { (Alnus })\end{array}$ & $7192 \pm 50$ & $6210-5987$ \\
\hline & & $\mathrm{P} 2861$ & $\begin{array}{l}\text { Cobelly gravelly } \\
\text { sand }\end{array}$ & 90.42 & Ua-54350 & Nutshell Corylus & $7302 \pm 37$ & $6231-6074$ \\
\hline & & $\begin{array}{l}\text { wooden fish trap F362 in } \\
\text { L187 }\end{array}$ & $\begin{array}{l}\text { Shell/Calcar-eous } \\
\text { gyttja }\end{array}$ & 88.95 & Ua-41897 & Salix twigs & $6878 \pm 40$ & $5846-5670$ \\
\hline & Northern basin & $\log 5$ & $\begin{array}{l}\text { Peat below } \\
\text { calcareous gyttja }\end{array}$ & 89.6 & Ua-41951 & $\begin{array}{c}\text { Catkin-bracts, seeds } \\
\text { (Betula) }\end{array}$ & $9652 \pm 82$ & $9265-8801$ \\
\hline
\end{tabular}


The sharp contact between the calcareous gyttja and the overlaying dark brown silty/sandy gyttja could indicate erosion. However, the difference in macroscopic content of the two layers, together with the ${ }^{14} \mathrm{C}$-dates, suggests only a limited hiatus and minor reworking of the calcareous gyttja (Table 2, Figure 7). Three macrofossil samples were collected from this dark brown gyttja, and it is possibly contemporary with the earliest traces of occupation in the area. The sand content is higher in the dark brown gyttja than in the calcareous gyttja, with the highest concentrations in the lowermost and uppermost part (86.25 and $86.75 \mathrm{~m}$ a.s.1.), indicating higher energy in the water (Figure 5). Plant macrofossils in the lower part of this layer are dated to $8200-7700$ cal BC (Figure 7), and it is likely that the material was accumulated in Ancient Lake Vättern (ALV), after its transgression over Lake Strandvägen, probably shortly after ca. $8000 \mathrm{cal} \mathrm{BC}$. This interpretation of ALV incursion is chronologically supported by the complete absence of Tilia pollen, as the ALV brings high concentrations of e.g., Betula-, Corylus- and Juniperus pollen into the small basin, and drown local shoreline shrubs such as Hippophäe and Salix (Figure 6). The plant macrofossils in the dark brown gyttja are dominated by species which commonly occur in the Mesolithic contexts at the site [9,34], and lack traces of the younger flora with meadow and weed vegetation, which characterize the medieval- and Iron age material at adjacent sites. The occurrence of elderberry (Sambucus nigra L.) and raspberry (Rubus idaeus L.) in the lower part of the gyttja may reflect Mesolithic gathering or the local flora. This interpretation is strengthened by the pollen flora, which contains early Holocene elderberry [35]. In e.g., the Czech Republic, elderberry has been found in Mesolithic archaeological contexts [60], but in Scandinavia, the earliest finds of seeds so far seem to be from the Middle Neolithic in Denmark [61]. Small amounts of charcoal occur in the middle and lower parts of the dark brown gyttja, possibly deriving from a contemporary occupation. The lowermost part of the unit is a coarse-detrital gyttja which is fining upwards from ca. $86.4 \mathrm{~m}$ a.s.l. This combination of changes in sand content, macrofossils and pollen are interpreted as a successive rise in the water level, leading to greater distance to the shore (Figures 5-7). Alternatively, the sediment could also be explained by reworking caused by a younger fluvial event, but the lack of plant macrofossils and pollen typical for the younger periods (e.g., Picea and Tilia pollen) make this unlikely. At $86.5 \mathrm{~m}$ a.s.l., the sediment is a fine-detrital gyttja with low sand content and high amounts of Chara sp. macrospores (oospores), indicating deeper water conditions (Figure 5). We interpret this sediment as deposited during the highest stand of ALV, reported to be $92.5 \mathrm{~m}$ a.s.l. by [27]. This would indicate that the local water depth at this time was at most six meters, which is very plausible, considering the micro- and macroscopic content. At $86.69 \mathrm{~m}$ a.s.l., a two $\mathrm{cm}$ sandy layer contains the lowermost distinct charcoal horizon ( $>20$ frag.), and the charcoal is, because of the high concentration, most likely of anthropogenic origin. This level can be interpolated to be 7500-7000 cal BC (Figure 7), and probably reflect the first fall in water level in the Vättern basin, as River Motala Ström is formed, causing a sudden regression. It is unclear if the gyttja only contains material deposited in ALV, or if some of the organic material may be reworked from the substratum of calcareous gyttja. It is noteworthy that a part of the organic material seems to originate from occupational waste, not only elderberries and a high amount of charcoal, but also fish scales and fruits of floating sweet grass (Glyceria flutans L.) In Scandinavia, this tasty water grass is recorded as collected food during the Middle Neolithic and later, e.g., in Alvastra Pile dwelling [62]. In the uppermost part (ca. 86.7-86.8 $\mathrm{m}$ a.s.l.), the unit is again a sandy coarse-detrital gyttja, which may reflect a lowering of the water level, causing the shore to move closer with its vegetation of reeds (Phragmites australis L.) and rush (Schoenoplectus lacustris Palla). The lowering of the water table is connected to the channel erosion and successive down-cutting of River Motala Ström, during the first regression event in Lake Vättern. The first Tilia-pollen appears in the uppermost part of the dark brown gyttja (coarse-detrital gyttja at $86.77 \mathrm{~m}$ a.s.l.), which dates it to ca. $6200 \mathrm{cal}$ BC or later [19], although the pollen grains appear to be corroded, which might indicate some redeposition.

Above the dark brown gyttja is a grey-brown sandier unit, with variable gyttja content, rich in e.g., gravel, charcoal, wood fragments and hazel nutshells (Corylus avellana L.) This sediment is interpreted as near-shore river sediment, deposited in the backwater adjacent to the Late Mesolithic 
settlement, but probably exposed to, e.g., channel erosion and flooding events. The contact between the two stratigraphical units is gradual, and the boundary is set to $86.8 \mathrm{~m}$ a.s.l., mainly based on macroscopic content (Figure 5). The macrofossil content is similar to the near-shore material in other sections [34], but also contains some species indicating shallow and stagnant water e.g., mare's tail (Hippuris vulgaris L.), sedges (Carex sp.) and alder. This unit is the most well-dated of all at Strandvägen, with numerous dates of charred (and uncharred) hazelnuts, telmatic macrofossils and numerous archaeological finds [9,58] (Table 2). The age of the material is Late Mesolithic (mainly $6000-5000$ cal BC), mixed with reworked older macrofossils, mainly originating from the calcareous gyttja. High concentrations of charales (Chara spp. and Nitella spp.) and mollusk shell fragments also corroborate this redeposition. The sediment texture of the layer seems to be composed of aggregated lumps of calcareous gyttja, a phenomenon characteristic for fine-grained sediments in fluvial regimes where the riverbed is eroded and redeposited. The pollen from the unit also indicates redeposition with slightly higher amounts of corroded pollen grains of mainly Pinus, Betula and Ulmus. However, the presence of uncorroded Tilia, and total absence of Picea-pollen (Figure 6), indicate that material younger or older than Late Mesolithic is unlikely to be present in the river sediment of section C 13,059. Younger dates occur in the upper parts of the unit, but these are from intrusive charred wooden stakes associated with a ritual context from early Iron age, belonging to the overlaying fen peat (Table 2).

Overlaying the river sediment is sandy fen peat (peat with coarse-detrital gyttja), rich in fragments of mosses, reed, and alder (Figure 5). The peat contains Picea pollen (Figure 6), which expanded in the Motala area during the early Iron age [19], and the unit is ${ }^{14} \mathrm{C}$-dated to the same age (Figure 7), although rich in Mesolithic macrofossil material in other sections. The unit is most likely deposited during the Iron Age, a period with a slightly higher water level than the Mesolithic.

\subsection{Kanaljorden Stratigraphy}

The small Kanaljorden basin is situated in a more elevated location, and more exposed to wave erosion than Strandvägen, as indicated by more sandy, well-sorted sediments. However, the higher and more northerly location has most likely protected the site from river erosion. The ${ }^{14} \mathrm{C}$-dated stratigraphy in $\log 3$ (Tables 2 and 3) corresponds to the different stages of the basin- the lowermost two (postglacial clay and calcareous gyttja) mirroring the sedimentary units in section C 13,059. However, unlike Strandvägen, in $\log 3$ (Table 3), the postglacial clay is coarsening upwards into silt and sand, interpreted as reflecting the isolation of the small lake basin (Lake Kanaljorden) from the Yoldia Sea. The Kanaljorden calcareous gyttja is very similar to the calcareous gyttja of Strandvägen, both in organogenic and minerogenic material [35]. The lowermost gyttja is ${ }^{14} \mathrm{C}$-dated on terrestrial macrofossils to an age around $9200-8800 \mathrm{cal} \mathrm{BC}$, and the uppermost interpreted age of the unit is ca. $8400-7900 \mathrm{cal} \mathrm{BC}$, based on a ${ }^{14} \mathrm{C}$-sample of birch seeds and catkin scales from Log 3 (Table 2, Figure 8). The sample was taken at the bottom of the layer of sand at $89.46 \mathrm{~m}$ a.s.l., slightly above the calcareous gyttja. It is likely redeposited material from a reworked part of the uppermost calcareous gyttja. As the macrofossils are fragile and prone to destruction, it is likely a single short redeposition event. The sandy gravel unit above the calcareous gyttja (Table 3 and adjacent sections) represent a significant hiatus, most likely caused by the erosional ALV transgression. The following period, approximately 8000-6200 cal BC, few terrestrial macrofossils accumulate in the basin, apart from charcoal dated to ca. 7340-7070 cal BC (Table 2). A wicker fish trap was encountered in the Kanaljorden basin at ca. $88.95 \mathrm{~m}$ a.s.l. [59] (Table 2), corresponding to the top layer of the unit of sandy peaty gyttja in Log 3 (Table 3). This is interpreted as shallow lake sediments, or beach zone strata, deposited during a period when the Kanaljorden basin was in contact with Lake Vättern. This layer was later covered by sediment that formed in the small isolated lake sometime after $6200 \mathrm{cal} \mathrm{BC}$, and by the man-made stone foundation that was built there shortly afterwards. The trap is dated to $5850-5650 \mathrm{cal}$ $\mathrm{BC}$, and ${ }^{14} \mathrm{C}$-dates of archaeological material deposited on top of the covering stone-packing are only marginally younger [12], indicating that the fish trap was built shortly before the end of the beach zone phase. A series of four ${ }^{14} \mathrm{C}$-samples that span the end of the phase is found in a $65 \mathrm{~cm}$ thick stratified 
sequence of redeposited silt, sand and peat, at $91.2 \mathrm{~m}$ a.s.l. (Table 2). These samples cover the time period $6220-5730 \mathrm{cal} \mathrm{BC}$, and suggest a similar terminus as the date of the fish trap. The overlaying peaty gyttja, deposited after 6220-5730 cal BC, indicates shallow water and low-energy conditions and is interpreted as representing an isolated lake/fen environment (Table 3).

Table 3. Lithology and sediment stratigraphy of $\log 3$ at Kanaljorden.

\begin{tabular}{|c|c|c|c|c|}
\hline Lithology $\log 3$ & & m a.s.l. & $\begin{array}{c}{ }^{14} \text { C-Samples } \\
\text { (m a.s.l.) }\end{array}$ & Interpreted Environment \\
\hline Peat & & $>89.62$ & & Fen/bog \\
\hline Peaty gyttja & & $89.56-89.62$ & $89.58-89.60$ & Fen \\
\hline & Sandy peaty gyttja & $89.50-89.56$ & & Beach deposit \\
\hline Sandy gyttja & Gravelly sandy gyttja (w. cobbles) & $89.44-89.50$ & $89.45-89.47$ & ALV transgression layer (erosional) \\
\hline Calcareous gyttja & & $89.18-89.44$ & $\begin{array}{c}89.355-89.375 \\
89.22-89.24\end{array}$ & Isolated lake basin (ILB) \\
\hline Blue-grey clay & & $89.14-89.18$ & & Yoldia Sea clay \\
\hline Boulders & & $89.08-89.14$ & & Glacial till \\
\hline
\end{tabular}

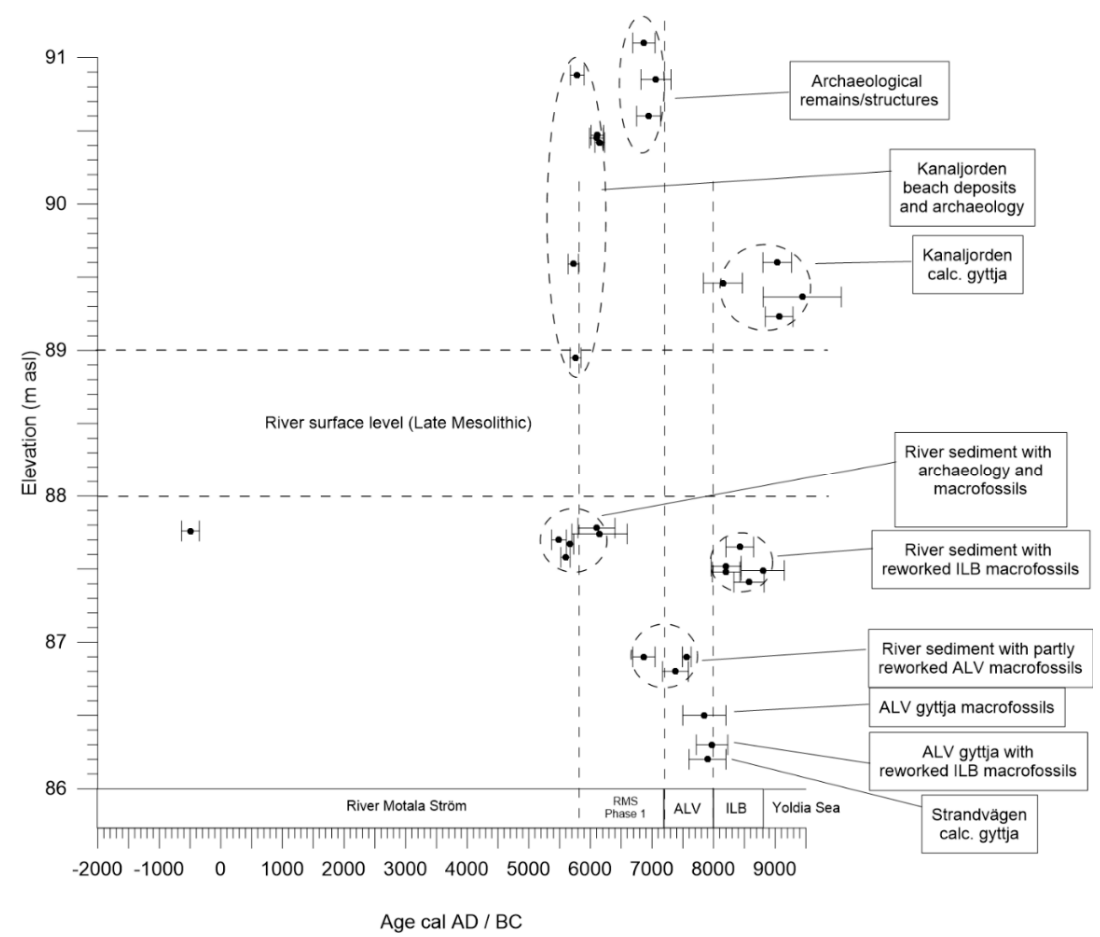

Figure 8. ${ }^{14} \mathrm{C}$-dates ( $2 \sigma$ error) from the isolated lake basins (ILB) calcareous gyttja (Lake Strandvägen and Lake Kanaljorden), Ancient Lake Vättern (ALV) transgression sandy units (Kanaljorden), ALV gyttja (Strandvägen), and river sediment (Strandvägen). Dates from sediment units in several sections, and at slightly varying elevation, are included in the figure. The ILB stage begins around 9000-8800 cal $\mathrm{BC}$, with the accumulation of calcareous gyttja. The ILB stage ends sometime after $8000 \mathrm{cal}$ BC-a short hiatus (less than 400 years) is likely as the calcareous gyttja is eroded by the ALV transgression. The ALV transgression reaches $92.5 \mathrm{~m}$ a.s.l. around 7500-7000 cal BC, according to dates from ALV gyttja, and dates from cultural structures/deposits indicate the regression to begin around $7200 \mathrm{cal}$ BC. After the rapid regression, during River Motala Ström (RMS) phase 1, Lake Vättern is likely at a still-stand between 90.5-91.5 m a.s.l., and in contact with the Kanaljorden basin, where sandy layers are deposited. During this period, few terrestrial macrofossils accumulate in the basins. At ca. $5800 \mathrm{cal}$ BC, archaeological material accumulates en masse around both archaeological settlements, as Lake Vättern falls to around $88.5 \mathrm{~m}$ a.s.l., completely isolating the Kanaljorden basin. The Strandvägen basin came in contact with the river, with partial erosion and redeposition of older sediments. Mainly the shallow, marginal parts of the Lake Strandvägen calcareous gyttja are reworked, and macrofossils are redeposited in the river sediment. Mesolithic ${ }^{14} \mathrm{C}$-dates are presented in Table 2. 


\section{Discussion}

\subsection{The Tilting of Lake Vättern and the Northern Outlet}

The N-S tilting of the Lake Vättern basin after the isolation in the north would have created an increasing available basin volume. Possibly, a large portion of the ALV water surplus (net runoff) would instead be swallowed by the continuously increasing available volume, negating or at least minimizing the northern outlet discharge. The pivot point for the tilting process was located at the northern threshold, meaning the whole basin experienced the ALV transgression, whereas as soon as River Motala Ström formed, the pivot point moved to Motala, and a regression began in the northern part of the basin. It is possible that this meant that no northern outlet existed during the ALV-stage in the early Holocene [22], depending on the rate of tilting.

\subsection{The Ancylus Lake in the Vättern Basin?}

The Ancylus transgression maximum around 8300-8200 cal BC has been recorded in the southern Baltic area but is not well documented further north [63]. According to [33], the Ancylus Lake and the Initial Littorina Sea reached into the Vättern basin before it was completely isolated from the Baltic basin. However, this interpretation seems to hinge on a few radiocarbon dates of unknown organic material. In our reconstruction, we have assumed that the minimum level of the ALV was $83 \mathrm{~m}$ a.s.1. (Figure 9; 80-86 $\mathrm{m}$ a.s.1. has been suggested as the ALV minimum [27,30]). This level is similar to the level of the Ancylus transgression shoreline found near Lake Boren, well below the threshold at Motala. According to [27], pronounced beach deposits are situated in the Askersund area at $104 \mathrm{~m}$ a.s.l., and these are interpreted as remnants of the Ancylus transgression maximum, inferring that the Ancylus transgression never entered the Vättern basin. Furthermore, in Närke, studies of small lake basins at 61.5-62.5 $\mathrm{m}$ a.s.l. showed they were isolated from the Initial Littorina Sea [52,64], making the presence of the Ancylus Lake, or the Initial Littorina Sea, in the Vättern basin improbable.

However, judging solely from the data presented in this paper, it is still possible that the early part of the ALV phase might have been in contact with the Ancylus Lake through a northern connection. Future studies of the isolation sequence from small lake basins in the Askersund area might help clarify this problem.

\subsection{Dating River Motala Ström and the River Formation Process}

The small kettlehole basins, Lake Strandvägen and Lake Kanaljorden, emerged from the Yoldia Sea around 9000-8800 cal BC, and in the isolated lake basins (ILB), the accumulation of calcareous gyttja started. The ILB stage ended sometime after $8000 \mathrm{cal}$ BC (probably 8000-7600 cal BC), as the calcareous gyttja was eroded by the ALV transgression (Figures 8 and 9).

As the local transgression continued, the threshold at $92.5 \mathrm{~m}$ a.s.l. was reached around $7200 \mathrm{cal} \mathrm{BC}$, and River Motala Ström was formed. The age is based on all available dated events: the interpolated Lake Boren diatom signal (7200-6900 cal BC), the archaeological structures and deposits at 90.5-91 m a.s.1. (7200-7000 cal BC), and the interpolated water depth decrease in section C 13,059 (7500-7000 cal BC). The ALV transgression left distinct beach ridges at Motala at a level of ca. $92.5 \mathrm{~m}$ a.s.1. [22,27]. It is possible that the rising shoreline in Motala caused massive groundwater infiltration into the glaciofluvial deposits, effectively slowing the transgression as it reached above ca. $90 \mathrm{~m}$ a.s.l. The groundwater aquifer in the sand and gravel material would then have been drained by springs on the eastern slope of the esker. These would, in turn, have created a small stream which drained into the Lake Boren basin. The rising ground water table of the glaciofluvial deposit would also have affected the water level of the two small isolated lake basins, making it rise as the ALV transgression progressed. In log 6 and 3 at Kanaljorden, and section C 13,059 at Strandvägen, the fining-upwards of the calcareous gyttja, and the macrofossil record indicate a water depth increase prior to the ALV transgression. 


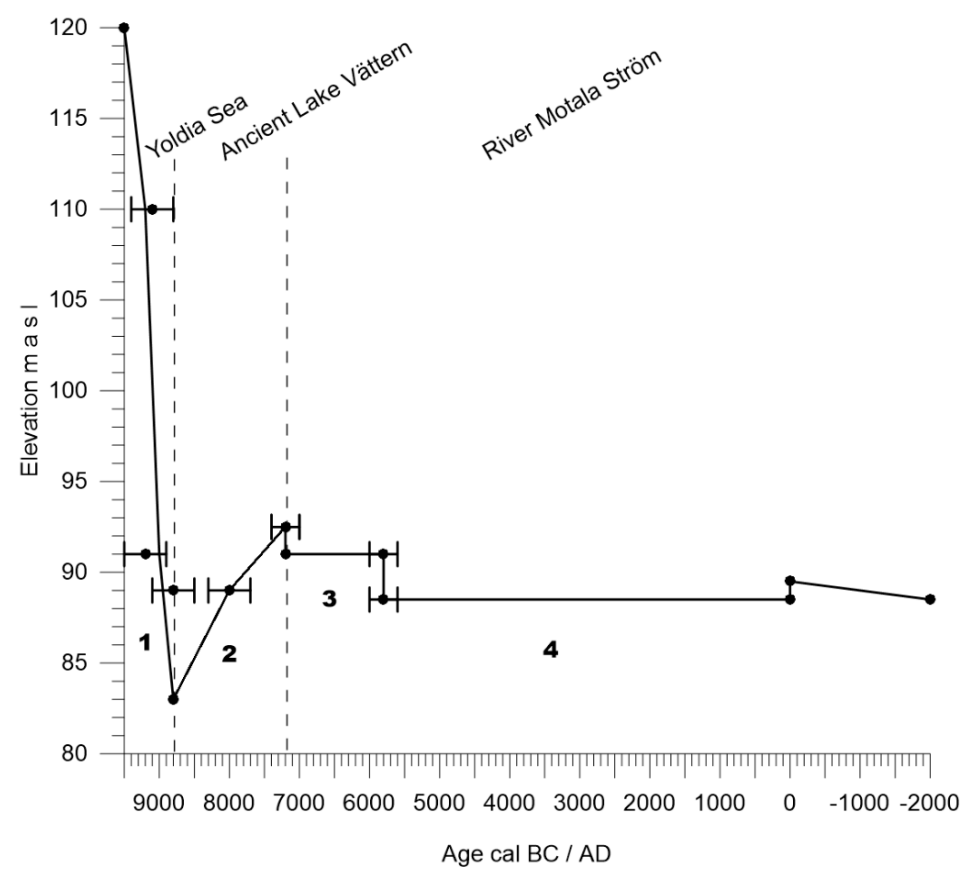

Figure 9. Shore displacement history in Motala. (1) The Yoldia Sea shoreline fall from ca. $120 \mathrm{~m}$ a.s.l., and Fågelstakärret fen (110 m a.s.l.) [19], Lake Kanaljorden (estimated threshold $91 \mathrm{~m}$ a.s.l.), and Lake Strandvägen (estimated threshold $89 \mathrm{~m}$ a.s.l.) become isolated around $8800 \mathrm{cal} \mathrm{BC}$. Ancient Lake Vättern (ALV) is isolated from the sea and drops to ca. $83 \mathrm{~m}$ a.s.l. (80-86; [27,30]. (2) ALV transgression starts as the northern connection is closed or possibly begin as part of the Ancylus Lake transgression. The Strandvägen and Kanaljorden basins become inundated shortly after 8000 cal BC. (3) River Motala Ström is first formed between 7500-6900 cal BC, and this first channel head (at the first rapid) was located east of Strandvägen. As it quickly erodes through glaciofluvial deposits, the Lake Vättern water level drops to ca. $91 \mathrm{~m}$ a.s.l. The Strandvägen site becomes an island, with early settlement remains, and the Kanaljorden basin most likely becomes part of the Lake Vättern beach zone during the Lake Vättern stillstand. (4) At $5800 \mathrm{cal} \mathrm{BC}$, the headward erosion has moved the channel head west to Strandvägen, and the Lake Vättern shoreline falls to ca. $88.5 \mathrm{~m}$ a.s.l., or slightly higher. The main Mesolithic settlements are founded at the first rapids. During the Early Iron Age (ca. 200 cal BC-100 cal $\mathrm{AD})$, the mean water level rises slightly, accommodating for accumulation of fen- and river peat in the backwater at Strandvägen. Events are based on one or several ${ }^{14} \mathrm{C}$-dated $(2 \sigma$ error) units or records.

During this first phase of River Motala Ström (Figure 9), the channel head (the first rapids) would have been located further east, gradually eroding the glaciofluvial deposits of the Lake Vättern threshold. It is a very likely scenario, even though this glaciofluvial threshold today is completely gone. Through headward erosion, the channel head then migrated upstream, to the west. It is uncertain if the threshold erosion and channel cut-down process was slow or sudden, but the dated archaeological shoreline deposits at 90.5-91 m a.s.l. favor the explanation with two threshold erosion events at ca. 7200 and $5800 \mathrm{cal} \mathrm{BC}$ (Figures 8 and 9). Moreover, the well-preserved raised beaches located 90-91 $\mathrm{m}$ a.s.l. at Varamon in Motala [5], and at Brevik on the western side of Lake Vättern [22], suggest an extended period of still-stand at $91 \mathrm{~m}$ level. The still-stand came to an end around $5800 \mathrm{cal} \mathrm{BC}$, and the wetland basin at Kanaljorden became once more a small isolated lake, without any connection to Lake Vättern nor the river (Figure 9). This small lake became a place of ritual deposition of the selected parts of disarticulated humans and animals, as well as artefacts and tools of bone, antler and stone $[12,65]$. The ritual depositions date to a time span of perhaps 200 years and then ceased. Around the same time, the lake was gradually overgrown by reeds and turned into a fen.

It is possible that the Holocene climatic evolution has played a role in the threshold, and channel, erosion process. Beginning around $6200 \mathrm{cal} \mathrm{BC}$, the so-called 8200-event marked the onset of the 
Northgrippian period [66], which may have brought increased effective moisture, as lower evaporation compensated for reduced precipitation [67]. The event itself may, however, not have brought wetter climate in Scandinavia, but a shift to higher precipitation amounts, or increased effective moisture, might have begun after the event itself, around $6000 \mathrm{cal} \mathrm{BC} \mathrm{(e.g.,} \mathrm{[68]).} \mathrm{Such} \mathrm{a} \mathrm{climate} \mathrm{change} \mathrm{might}$ have raised the regional lake water levels, and eventually, triggered an erosion event as the river discharge increased.

As the river course stabilized, it gave the hunter-gatherers in Motala excellent regional contact routes, and the basis for a more sedentary lifestyle. The archaeological record suggests a year-round presence during the Late Mesolithic, mostly relying on stationary fishing [9]. And perhaps, the people who lived by the river shared tales around the hearth of the day when the river began.

Author Contributions: Conceptualization, J.B.; Investigation, J.B., A.P., L.H., F.H., J.R., and F.M.; Writing-original draft presentation, J.B., A.P., J.H., L.H., F.H., J.R. and F.M.; Writing-review and editing, J.B., A.P., F.H. and F.M.; Methodology, J.B., A.P., J.H. and J.R.; project administration, F.H. and F.M.; Funding acquisition, F.H. and F.M. All authors have read and agreed to the published version of the manuscript.

Funding: The archaeological excavations in Motala have been conducted within the Swedish contract archaeology system and have been funded by the Swedish Transport Administration after the decision from the local authorities of the cultural heritage sector, the County Administration of Östergötland.

Acknowledgments: We would like to thank the three anonymous reviewers for their valuable comments on the manuscript.

Conflicts of Interest: The authors declare no conflict of interest.

\section{References}

1. Lindén, M.; Möller, P.; Björck, S. Holocene shore displacement and deglaciation chronology in Norrbotten, Sweden. Boreas 2006, 35, 1-22. [CrossRef]

2. Saarnisto, M. Late Holocene land uplift/neotectonics on the island of Valamo (Valaam), Lake Ladoga, NW Russia. Quat. Int. 2012, 260, 143-152. [CrossRef]

3. Preusser, F.; May, J.-H.; Eschbach, D.; Trauerstein, M.; Schmitt, L. Infrared stimulated luminescence dating of 19th century fluvial deposits from the upper Rhine River. Geochronometria 2016, 43, 131-142. [CrossRef]

4. Mulligan, R.P.M.; Eyles, C.H.; Bajc, A.F. Stratigraphic analysis of Late Wisconsin and Holocene glaciolacustrine deposits exposed along the Nottawasaga River, southern Ontario, Canada. Can. J. Earth Sci. 2018, 55, 863-885. [CrossRef]

5. Johansson, H.G. Description to the Quaternary Map Linköping NV; Series Ae 24; Swedish Geological Survey: Stockholm: Sweden, 1976; p. 102.

6. Molin, F.; Gruber, G.; Hagberg, L. Motala-A North European Focal Point? In Lateglacial and Postglacial Pioneers in Northern Europe; Riede, F., Tallavaara, M., Eds.; BAR International Series 2599; Archaeopress: Oxford, UK, 2014; pp. 91-102.

7. Hagberg, L.; Westermark, A. Material culture and Mesolithic actions in space: Results of the spatial analysis of the Verkstadsvägen site in Motala. In Muge 150th: The 150th Anniversary of the Discovery of Mesolithic Shellmiddens-Volume 2; Bicho, N., Detry, C., Price, T.D., Cunha, E., Eds.; Cambridge Scholars Publishing: Newcastle Upon Tyne, UK, 2015; pp. 219-234.

8. Gummesson, S.; Molin, F. The Mesolithic cemetery at Strandvägen, Motala, in eastern central Sweden. In Mesolithic Burials-Rites, Symbols and Social Organisation of Early Postglacial Communities, Proceedings of the International Conference, Halle (Saale), Germany, 18-21 September 2013; Tagungen des Landesmuseums für Vorgeschichte Halle (Saale); Grünberg, J.M., Gramsch, B., Larsson, L., Orschiedt, J., Meller, H., Eds.; Landesamt für Denkmalpflege und Archäologie Sachsen-Anhalt, Landesmuseum für Vorgeschichte: Halle (Saale), Germany, 2016; Volume 13, pp. 145-159.

9. Molin, F.; Hagberg, H.; Westermark, A. Living by the Shore: Mesolithic Dwellings and Household in Motala, Eastern Central Sweden, 5000-5600 cal BC. J. Archaeol. Sci. Rep. 2018, 18, 913-924. [CrossRef]

10. Bergman, J. Stone age disease in the north-Human intestinal parasites from a Mesolithic burial in Motala, Sweden. J. Archaeol. Sci. 2018, 96, 26-32. [CrossRef] 
11. Carlsson, T. Where the River Bends under the Boughs of Trees: Strandvägen-A Late Mesolithic Settlement in Eastern Middle Sweden; Riksantikvarieämbetet: Stockholm, Sweden, 2008.

12. Hallgren, F.; Fornander, E. Skulls on stakes and skulls in water. Mesolithic mortuary rituals at Kanaljorden, Motala, Sweden 7000 BP. In Mesolithic Burials-Rites, Symbols and Social Organisation of Early Postglacial Communities, Proceedings of the International Conference Halle (Saale), Germany, 18-21 September 2013; Tagungen des Landesmuseums für Vorgeschichte Halle (Saale); Grünberg, J.M., Gramsch, B., Larsson, L., Orschiedt, J., Meller, H., Eds.; Landesamt für Denkmalpflege und Archäologie Sachsen-Anhalt, Landesmuseum für Vorgeschichte: Halle (Saale), Germany, 2016; Volume 13, pp. 161-174.

13. Hallgren, F. A small Preboreal settlement site at Kanaljorden, Motala, Sweden. In The Ecology of Early Settlement in Northern Europe: Conditions for Subsistence and Survival; The Early Settlement of Northern Europe; Persson, P., Skar, B., Breivik, H.M., Eds.; Equinox Publishing Ltd.: Sheffield, UK, 2018; Volume 1, pp. 221-244.

14. Björck, S.; Andrén, T.; Jensen, J.B. An Attempt to Resolve the Partly Conflicting Data and Ideas on the Ancylus-Littorina Transition. Pol. Geol. Inst. Spec. Pap. 2008, 23, 21-26.

15. Björck, J.; Possnert, G.; Schoning, K. Early Holocene deglaciation chronology in Västergötland and Närke, southern Sweden-Biostratigraphy, clay varve, 14C and calendar year chronology. Quat. Sci. Rev. 2001, 20, 1309-1326. [CrossRef]

16. Björck, S. The late Quaternary development of the Baltic Sea. In Assessment of Climate Change for the Baltic Sea Basin; The BACC Author Team, Ed.; Springer: Heidelberg, Germany, 2008; pp. 398-407.

17. Andrén, T.; Björck, S.; Andrén, E.; Conley, D.; Zillén, L.; Anjar, J. The development of the Baltic Sea Basin during the Last 130 ka. In The Baltic Sea Basin; Harff, J., Björck, S., Hoth, P., Eds.; Springer: Heidelberg, Germany, 2011; pp. 75-98.

18. Hansson, A.; Björck, S.; Heger, K.; Holmgren, S.; Linderson, H.; Magnell, O.; Nilsson, B.; Rundgren, M.; Sjöström, A.; Hammarlund, D. Shoreline displacement and human resource utilization in the southern Baltic Basin coastal zone during the early Holocene: New insights from a submerged Mesolithic landscape in south-eastern Sweden. Holocene 2017, 28, 721-737. [CrossRef]

19. Karlsson, S.; Larsson, L.K. Vegetationshistoria i Fågelstaområdet, västra Östergötland. Fågelstaprojektet. Fem arkeologiska undersökningar i västra Östergötlands slättbygd. UV Öst Rep. 2008, 29, 1-22.

20. Plikk, A.; Risberg, J. Kvartärgeologiska undersökningar i Skänninge och Västra Stenby socken, Östergötland. In 10000 år vid Södra Freberga; Carlsson, T., Ed.; Statens Historiska Museer: Stockholm, Sweden, 2021; in press.

21. Hansson, A.; Boethius, A.; Hammarlund, D.; Lagerås, P.; Magnell, O.; Nilsson, B.; Brunlid, A.N.; Rundgren, M. Shorline displacement, coastal environments and human subsistence in the Hanö Bay Region during the Mesoltihic. Quaternaria 2019, 2, 14. [CrossRef]

22. Nilsson, E. The Late-quaternary history of southern Sweden. Geochronology, ice-lakes, land-uplift. K. Sven. Vetensk. Handl. Fjärde Ser. 1968, 12, 1-117.

23. Fromm, E. Description to the Quaternary map Linköping NO; Series Ae 19; Swedish Geological Survey: Stockholm, Sweden, 1976; p. 77.

24. Björck, S. A review of the history of the Baltic Sea, 13.0-8.0 ka BP. Quat. Int. 1995, 27, 19-40. [CrossRef]

25. Björck, S.; Svensson, N.O. Östersjöns och Västerhavets utveckling. In Berg Och Jord; Fredén, C., Ed.; Sveriges Nationalatlas: Vällingby, Sweden, 2002; pp. 138-142.

26. Andrén, E.; Andrén, T.; Sohlenius, G. The Holocene history of the southwestern Baltic Sea as reflected in a sediment core from the Bornholm Basin. Boreas 2000, 29, 233-250. [CrossRef]

27. Munthe, H. Till frågan om Vätterns senkvartära historia. Geol. Föreningens Stockh. Förhandlingar 2018, 57, 29-46. [CrossRef]

28. Nilsson, E. Bidrag till Vätterns och Bolmens senkvartära historia. Geol. Föreningens Stockh. Förhandlingar 1937, 59, 189-204. [CrossRef]

29. Nilsson, E. Södra Sveriges senkvartära historia. Geol. Föreningens Stockh. Förhandlingar 1953, 75, $155-246$. [CrossRef]

30. Norrman, J.O. Vätterbäckenets senkvartära strandlinjer. Geol. Föreningens Stockh. Förhandlingar 1964, 85, 391-413. [CrossRef]

31. Granlund, E. Vättern och landhöjningen—Mäster Gudmund Gilles Årsbok; Mäster Gudmunds Gille: Jönköping, Sweden, 1933; pp. 11-35.

32. Svantesson, S.-I. Beskrivning till jordartskartan Jönköping SV. Sver. Geol. Undersökning 1985, 59, 1-171. 
33. Swärd, H.; O’Regan, M.; Björck, S.; Greenwood, S.L.; Kylander, M.E.; Mörth, C.-M.; Pearce, C.; Jakobsson, M. A chronology of environmental changes in the Lake Vättern basin from deglaciation to final isolation. Boreas 2018, 47, 609-624. [CrossRef]

34. Bergman, J.; Heimdahl, J.; Hagberg, L. Kvartärgeologi och paleoekologi vid Strandvägen. In Strandvägen —Mesolitisk Boplats och Gravfält i Motala; Molin, F., Hagberg, L., Westermark, A., Zetterlund, P., Eds.; Arkeologerna: Stockholm, Sweden, 2021; in press.

35. Plikk, A.; Regnell, M.; Risberg, J. Miljöförändringar i södra Motala stad, 1000-1,010,000 BC. In Kanaljorden, Motala_Rituella Våtmarksdepositioner och Boplatslämningar Från Stenåldern; Hallgren, F., Ed.; Stiftelsen Kulturmiljövård: Västerås, Sweden, 2021; in press.

36. Wasylikowa, K. Analysis of fossil fruits and seeds. In Handbook of Holocene Palaeoecology and Palaeohydrology; Berglund, B.E., Ed.; John Wiley \& Sons Ltd.: Chichester, UK, 1986; pp. 571-590.

37. Berggren, G. Atlas of Seeds. Part 2. Cyperaceae; Swedish Natural Science Research Council: Stockholm, Sweden, 1969.

38. Berggren, G. Atlas of Seeds. Part 3. Salicaceae Cruciferae; Swedish Natural Science Research Council: Stockholm, Sweden, 1981.

39. Anderberg, A.-L. Atlas of Seeds. Part 4. Resedaceae-Umbelliferae; Naturhistoriska Riksmuseet: Stockholm, Sweden, 1994.

40. Cappers, R.T.T.; Neef, R.; Bekker, R.-M. Digital Atlas of Economic Plants; Groningen Archaeological Studies vol 9; Barkhuis: Groningen, The Netherlands, 2009.

41. Berglund, B.E.; Ralska-Jasiewiczowa, M. Pollen analysis and pollen diagrams. In Handbook of Holocene Palaeoecology and Palaeohydrology; Berglund, B.E., Ed.; Wiley: Chichester, UK, 1986; pp. 455-484.

42. Beug, H.-J. Leitfaden der Pollenbestimmung fûr Mitteleuropa und Angrenzende Gebiete; Verlag Dr. Friedrich Pfeil: Mûnchen, Germany, 2004; p. 542.

43. Bronk Ramsey, C. Bayesian Analysis of Radiocarbon Dates. Radiocarbon 2009, 51, 337-360. [CrossRef]

44. Reimer, P.J.; Bard, E.; Bayliss, A.; Beck, J.W.; Blackwell, P.G.; Ramsey, C.B.; Buck, C.E.; Cheng, H.; Edwards, R.L.; Friedrich, M.; et al. Intcal13 and Marine13 Radiocarbon Age Calibration Curves 0-50,000 Years Cal BP. Radiocarbon 2013, 55, 1869-1887. [CrossRef]

45. Battarbee, R.W. Diatom analysis. In Handbook of Holocene Palaeoecology and Palaeohydrology; Berglund, B.E., Ed.; John Wiley \& Sons: Chichester, UK, 1986; pp. 527-570.

46. Krammer, K.; Lange-Bertalot, H. Bacillariophyceae. 1.Teil: Naviculaceae. In Süsswasserflora von Mitteleuropa, 2/1; Gustav Fischer Verlag: Stuttgart, Germany, 1986; 876p.

47. Krammer, K.; Lange-Bertalot, H. Bacillariophyceae. 2.Teil: Bacillariaceae, Epithemiaceae, Surirellaceae. In Süsswasserflora von Mitteleuropa, 2/2; Gustav Fischer Verlag: Stuttgart, Germany, 1988; 596p.

48. Krammer, K.; Lange-Bertalot, H. Bacillariophyceae. 3.Teil: Centrales, Fragilariaceae, Eunotiaceae. In Süsswasserflora von Mitteleuropa, 2/3; Gustav Fischer Verlag: Stuttgart, Germany, 1991; 576p.

49. Krammer, K.; Lange-Bertalot, H. Bacillariophyceae. 4.Teil: Achnanthaceae. Kritische Ergänzungen zur Navicula (Lineolate) und Gomphonema. In Süsswasserflora von Mitteleuropa, 2/4; Gustav Fischer Verlag: Stuttgart, Germany, 1991; 437p.

50. Eronen, M. The history of the Litorina Sea and associated Holocene events. Comment. Phys. Math. Soc. Sci. Fenn. 1974, 44, 79-195.

51. Risberg, J. Palaeoenvironment and Sea Level Changes during the Early Holocene on the Södertörn Peninsula, Södermanland, Eastern Sweden. Ph.D. Thesis, Stockholm University, Stockholm, Sweden, 1991; 27p.

52. Hedenström, A.; Risberg, J. Early Holocene shore-displacement in southern central Sweden as recorded in elevated isolated basins. Boreas 1999, 28, 490-504. [CrossRef]

53. Bergström, S.M.; Calner, M.; Lehnert, O.; Noor, A. A new upper Middle Ordovician-Lower Silurian drillcore standard succession from Borenshult in Östergötland, southern Sweden: 1. Stratigraphical review with regional comparisons. GFF 2011, 133, 149-171. [CrossRef]

54. Bona, F.; Falasco, E.; Fassina, S.; Griselli, B.; Badino, G. Characterization of diatom assemblages in mid-altitude streams of NW Italy. Hydrobiologia 2007, 583, 265-274. [CrossRef]

55. King, L.; Clarke, G.; Bennion, H.; Kelly, M.; Yallop, M. Recommendations for sampling littoral diatoms in lakes for ecological status assessments. Environ. Boil. Fishes 2006, 18, 15-25. [CrossRef] 
56. Hargan, K.E.; Rühland, K.M.; Paterson, A.M.; Finkelstein, S.A.; Holmquist, J.R.; Macdonald, G.M.; Keller, B.W.; Smol, J.P. The influence of water-table depth and $\mathrm{pH}$ on the spatial distribution of diatom species in peatlands of the Boreal Shield and Hudson Plains, Canada. Botany 2015, 93, 57-74. [CrossRef]

57. Krause, W. Charales (Charophyceae). In Süsswasserflora von Mitteleuropa, 18; Gustav Fischer Verlag: Jena, Germany, 1997; 202p.

58. Molin, F.; Hagberg, L.; Westermark, A.; Zetterlund, P. Strandvägen-Mesolitisk Boplats och Gravfält i Motala; Arkeologerna, Rapport; Statens Historiska Museer: Stockholm, Sweden, 2021; in press.

59. Hallgren, F. Kanaljorden, Motala-Rituella Våtmarksdepositioner och Boplatslämningar Från Stenåldern; Stiftelsen Kulturmiljövård: Västerås, Sweden, 2021; in press.

60. Divišová, M.; Šída, P. Plant Use in the Mesolithic Period. Archaeobotanical Data from the Czech Republic in a European Context-A Review. Interdiscip. Archaeol. Nat. Sci. Archaeol. 2015, 6, 95-106. [CrossRef]

61. Regnell, M. Archaeobotanical Finds from the Stone Age of the Nordic Countries: A Catalogue of Plant Remains from Archaeological Contexts; Lundqua Report 36; Lund University, Department of Quaternary Geology: Lund, Sweden, 1998; 27p.

62. Göransson, H. Alvastra Pile Dwelling: Palaeoethnobotanical Studies; Lund University Press: Lund, Sweden, 1995.

63. Björck, S.; Dennegård, B.; Sandgren, P. The marine stratigraphy of the Hanö Bay, SE Sweden, based on different sediment stratigraphic methods. Geol. Föreningens Stockh. Förhandlingar 1990, 112, 265-280. [CrossRef]

64. Karlsson, S.; Risberg, J. Holocen Miljöhistoria i Centrala Närke. UV Rep. 1997, 38, 1-84.

65. Gummesson, S.; Hallgren, F.; Kjellström, A. Keep your head high: Skulls on stakes and cranial trauma in Mesolithic Sweden. Antiquity 2018, 92, 74-90. [CrossRef]

66. Cohen, K.M.; Harper, D.A.T.; Gibbard, P.L. 2020 ICS International Chronostratigraphic Chart 2020/03; International Commission on Stratigraphy, IUGS. Available online: www.stratigraphy.org (accessed on 3 May 2020).

67. Holmes, J.A.; Tindall, J.; Roberts, N.; Marshall, W.; Marshall, J.D.; Bingham, A.; Feeser, I.; O'Connell, M.; Atkinson, T.; Jourdan, A.-L.; et al. Lake isotope records of the 8200-year cooling event in western Ireland: Comparison with model simulations. Quat. Sci. Rev. 2016, 131, 341-349. [CrossRef]

68. Bergman, J.; Hammarlund, D.; Hannon, G.; Barnekow, L.; Wohlfarth, B. Deglacial vegetation succession and Holocene tree-limit dynamics in the Scandes Mountains, west-central Sweden: Stratigraphic data compared to megafossil evidence. Rev. Palaeobot. Palynol. 2005, 134, 129-151. [CrossRef] 